\title{
Influence of terrestrial organic matter in marine food webs of the Beaufort Sea shelf and slope
}

\author{
Lauren E. Bell ${ }^{1, *}$, Bodil A. Bluhm ${ }^{1,2}$, Katrin Iken ${ }^{1}$ \\ ${ }^{1}$ University of Alaska Fairbanks, School of Fisheries and Ocean Sciences, 905 N. Koyukuk Dr., Fairbanks, AK 99775, USA \\ ${ }^{2}$ Present address: UiT - The Arctic University of Norway, Department of Arctic and Marine Biology, PO Box 6050 Langnes, \\ 9037 Tromsø, Norway
}

ABSTRACT: Forecasted increases in terrestrial organic matter $\left(\mathrm{OM}_{\text {terr }}\right)$ inputs to the Arctic Beaufort Sea necessitate a better understanding of the proportional contribution of this potential food source to the trophic structure of marine communities. This study investigated the relative ecological importance of $\mathrm{OM}_{\text {terr }}$ across the Beaufort Sea shelf and slope by examining differences in community trophic structure concurrent with variation in terrestrial versus marine organic matter influence. Oxygen stable isotope ratios $\left(\delta^{18} \mathrm{O}\right)$ of surface water confirmed the widespread influence of Canada's Mackenzie River plume across the Beaufort Sea. Carbon stable isotope ratios $\left(\delta^{13} \mathrm{C}\right)$ of pelagic particulate organic matter (pPOM) and marine consumers indicated a significant decrease in $\mathrm{OM}_{\text {terr }}$ presence and utilization by consumers with increasing distance from the Mackenzie River outflow. Food web length, based on the nitrogen stable isotope ratios $\left(\delta^{15} \mathrm{~N}\right)$ of marine consumers, was greater closer to the Mackenzie River outflow both in shelf and slope locations, due to relatively higher $\delta^{15} \mathrm{~N}$ values of pelagic and benthic primary consumers. Strong microbial processing of $\mathrm{OM}_{\text {terr }}$ in the eastern regions of the Beaufort Sea is inferred based on a trophic gap between assumed end members and lower trophic consumers. A greater proportion of relative epifaunal biomass occupying higher trophic levels suggests that $\mathrm{OM}_{\text {terr }}$ as a basal food source can provide substantial energetic support for higher marine trophic levels. These findings challenge the current conception of low terrestrial matter usage in the Arctic marine food web, and indicate the need for a more specific understanding of energy transfer through the $\mathrm{OM}_{\text {terr }}$-associated microbial loop.

KEY WORDS: Stable isotopes · Carbon - Nitrogen · Trophic structure · Microbial loop · Mackenzie River · Arctic

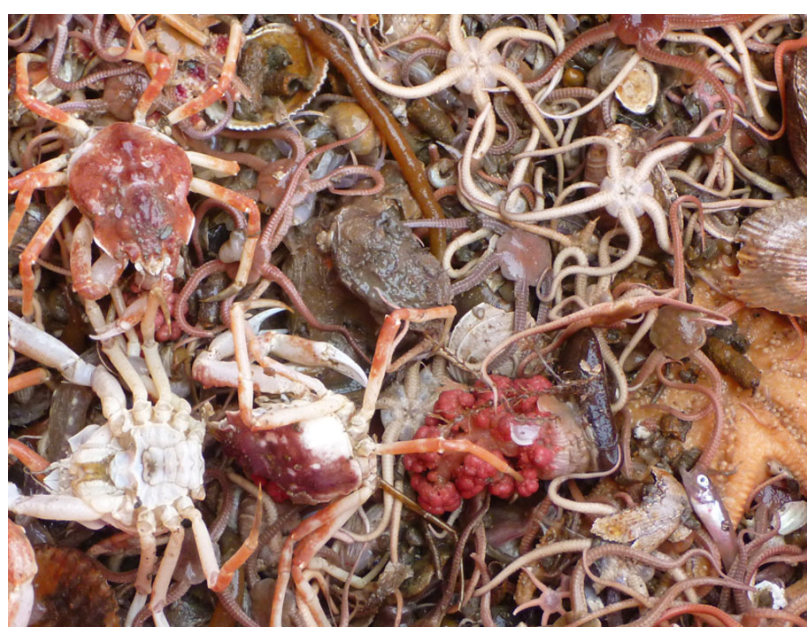

An epibenthic trawl haul from the Beaufort Sea shelf. Terrestrial organic matter may provide a greater basal energy source to Arctic marine consumers than previously thought.

Photo: Katrin Iken

\section{INTRODUCTION}

Coastal erosion and river discharge along the Arctic USA-Canada coastline result in the deposition of large amounts of terrestrially derived organic matter $\left(\mathrm{OM}_{\text {terr }}\right)$ into the Beaufort Sea of the Arctic Ocean (Macdonald et al. 1998, Rachold et al. 2004, Goñi et al. 2013). Compared with marine production, unmodified $\mathrm{OM}_{\text {terr }}$ is less labile, nutrient-poor, and reputed to be difficult for marine primary consumers to assimilate directly (Dunton et al. 2012). Additional microbial decomposition is needed to transform $\mathrm{OM}_{\text {terr }}$ into a useable food source for marine consumers (Tenore 1983, Garneau et al. 2009), a process that has histori-

() The authors 2016. Open Access under Creative Commons by Attribution Licence. Use, distribution and reproduction are unrestricted. Authors and original publication must be credited. 
cally been presumed to result in inefficient energy transfer from $\mathrm{OM}_{\text {terr }}$ to higher trophic levels of marine food webs (Schell 1983, Dunton et al. 1989, Berglund et al. 2007). In contrast, marine environments with tight coupling between primary production and benthic consumers are often considered indicative of high energy transfer efficiency because of the short trophic pathway from baseline food source to consumers (Dunton et al. 2005, Iken et al. 2010). Following this reasoning, the longer food webs resulting from the additional trophic steps involved in microbial metabolism of $\mathrm{OM}_{\text {terr }}$ could be symptomatic of a poorquality food source and inefficient energy transfer (e.g. Rosenzweig 1971, Abrams \& Roth 1994).

Nearshore lagoons and river deltas of the Beaufort Sea contain, contrary to previous assumptions, unexpectedly productive biological communities where $\mathrm{OM}_{\text {terr }}$ functions as a primary food source and food webs are relatively long (Dunton et al. 2012, OrtegaRetuerta et al. 2012, Casper et al. 2015). Modern food web theory proposes that food web length is not solely indicative of system productivity or trophic transfer efficiency, but is a result of many complex and interrelated system attributes, such as ecosystem size, resource availability, or vulnerability to disturbance (Post 2002a, Arim et al. 2007). Furthermore, terrestrially associated microbial metabolism is becoming increasingly understood as both an efficient and quality-enhancing process, functioning as a trophic connection between $\mathrm{OM}_{\text {terr }}$ and marine consumers (Klein Breteler et al. 1999, Lefébure et al. 2013, Rontani et al. 2014). Thus, past presumptions of $\mathrm{OM}_{\text {terr }}$ as a poor food source for marine consumers based solely on food web length need re-evaluating.

The goal of this study was to examine the extent to which $\mathrm{OM}_{\text {terr }}$ influences the offshore Arctic marine food webs of the Beaufort Sea, from shelf to basin. Coastal erosion is a large vector of $\mathrm{OM}_{\text {terr }}$ to the marine consumers of the Alaskan Beaufort Sea (Goñi et al. 2013); in addition, Canada's Mackenzie River in the eastern Beaufort Sea delivers more terrestrially derived suspended particulate matter to the Arctic Ocean (summer mass export of suspended particulate matter estimated at $3 \times 10^{13} \mathrm{~g} \mathrm{~m}^{-3}$, Doxaran et al. 2015) than all other Arctic rivers combined (Rachold et al. 2004). Increasing presence and biological utilization of $\mathrm{OM}_{\text {terr }}$ with proximity to the Mackenzie Delta has been inferred from stable isotope values of food sources and biota on the Beaufort shelf westward of the river (Schell et al. 1998, Goñi et al. 2000). Though this along-shelf gradient of $\mathrm{OM}_{\text {terr }}$ influence from the Mackenzie River affects trophic structure in the nearshore Beaufort Sea (Dunton et al. 2006,
2012), the extent to which it is reflected in the benthic marine food webs farther offshore on the shelf and on the slope of the Arctic basin is unknown. The potential of terrigenous carbon to influence food webs on the outer Beaufort shelf and slope is high: satellite images have captured the sediment plume exiting the Mackenzie River extending more than $400 \mathrm{~km}$ off-shelf (Macdonald et al. 1999) and large fluxes of terrestrially derived carbon have been recorded in the water column over the $500 \mathrm{~m}$ isobath of the slope (Forest et al. 2007). The substantial mobility of Mackenzie-derived $\mathrm{OM}_{\text {terr }}$ across the Beaufort shelf and into the Canada Basin has been explored thoroughly in sedimentary markers (Goñi et al. 2013), yet consideration of how this $\mathrm{OM}_{\text {terr }}$ influences the biota of offshore and deep-sea communities in the Arctic Ocean has been inadequate, especially given the potential of terrestrially derived food subsidies for deep-sea consumers elsewhere (Dittmar 2004).

$\mathrm{OM}_{\text {terr }}$ from high-latitude rivers enters the Arctic Ocean in 2 forms: the majority as dissolved organic matter (DOM) and the remainder as particulate organic matter (POM) (Macdonald et al. 1998). While our study focuses on the food web members that assimilate POM and not DOM (we therefore refer to $\mathrm{OM}_{\text {terr }}$ as the particulate form in this study), it is important to realize that concentrations of terrestrialorigin dissolved organic nitrogen and phosphorus on the Beaufort shelf in front of the Mackenzie River Delta are some of the highest reported in the Arctic Ocean (Emmerton et al. 2008), and a large percentage $(30-70 \%)$ of this DOM input can be semilabile (Hansell et al. 2004, Cooper et al. 2005). Degradation and remineralization of riverine DOM by microbial communities in the Arctic Ocean can constitute a significant portion of bacterial and phytoplankton production (Sipler \& Bronk 2015). Recognizing the contribution that DOM can make to microbial production, the intent of this study was to identify whether $\mathrm{OM}_{\text {terr }}$ could be tracked into invertebrate and fish tissues.

Tracking of organic matter provenance and energy flow in aquatic food webs is commonly accomplished using the well-vetted technique of stable isotope analysis. Carbon derived from terrestrial plant production at high latitudes is isotopically lighter (Wooller et al. 2007) than carbon formed from marine primary production (Naidu et al. 1993 and references therein), so that the carbon stable isotope ratio $\left(\delta^{13} \mathrm{C}\right)$ of an organic matter sample can indicate the relative end member source composition of that sample. While $\mathrm{OM}_{\text {terr }}$ often represents a complex mixture of sources, such as freshwater aquatic production, modern ter- 
restrial plant production, and ancient eroded peat (Connelly et al. 2015), the $\delta^{13} \mathrm{C}$ value of $\mathrm{OM}_{\text {terr }}$ remains distinctly lower than marine production regardless of its specific composition. Marine microbial activity may alter the isotopic composition of all POM over time (Mintenbeck et al. 2007, Robinson et al. 2012), masking the original isotopic signature of the source end member. For the purposes of this study, terminology such as ' $\mathrm{OM}_{\text {terr' }}$ or 'marine' organic matter refers to the supposed origin or source location of the matter, regardless of the degree of microbial processing that followed. Nitrogen stable isotope ratios $\left(\delta^{15} \mathrm{~N}\right)$ show an enrichment of the heavier isotope $\left({ }^{15} \mathrm{~N}\right)$ between food source and consumer due to trophic fractionation (Vander Zanden \& Rasmussen 2001, Post 2002b, Hussey et al. 2014), allowing for the depiction of food webs based on the $\delta^{15} \mathrm{~N}$ values of consumers relative to their baseline food source.

In addition to measuring the $\delta^{13} \mathrm{C}$ and $\delta^{15} \mathrm{~N}$ values of particulate organic matter, oxygen stable isotope ratios $\left(\delta^{18} \mathrm{O}\right)$ of surface waters can be used to trace the mixing of a freshwater source into the marine system, thereby providing an additional proxy of a potential pathway of $\mathrm{OM}_{\text {terr }}$ entrained in this freshwater into the Arctic Ocean. $\delta^{18} \mathrm{O}$ values of precipitation worldwide vary predictably due to oxygen isotope fractionation during the global water cycle (Gat 1996 and references therein), imparting specific isotopic values to high latitude, river-derived freshwater. This enables the use of these isotopes to distinguish whether freshwater mixing into an Arctic marine system originated from a river or from surface sea-ice melt (Lansard et al. 2012). In this study, $\delta^{18} \mathrm{O}$ values were used to track freshwater from the Mackenzie River plume in the surface waters over the Beaufort Sea shelf and slope.

High freshwater outflow from Canada's Mackenzie River between May and September brings suspended inorganic sediment $\left(>127 \mathrm{Tg} \mathrm{yr}^{-1}\right)$ and $\mathrm{OM}_{\text {terr }}$ $\left(>3.4 \mathrm{Tg}\right.$ total $\mathrm{C} \mathrm{yr}^{-1}$ ) into the eastern Beaufort Sea (Macdonald et al. 1998, Doxaran et al. 2015). $\mathrm{OM}_{\text {terr }}$ inputs from the Mackenzie River dwarf contributions of $\mathrm{OM}_{\text {terr }}$ into the Beaufort from other vectors, such as coastal erosion $\left(\sim 0.5 \mathrm{Tg} \mathrm{C} \mathrm{yr}^{-1}\right.$, Rachold et al. 2000, Ping et al. 2011) and the next 3 largest rivers in the Beaufort region: the Colville, Kuparuk, and Saga-

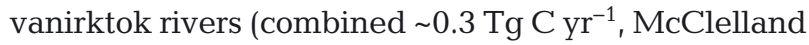
et al. 2014). As such, the Beaufort Sea is characterized by a distinct gradient of increasingly diluted freshwater and $\mathrm{OM}_{\text {terr }}$ with horizontal distance from the Mackenzie Delta and with increasing depth across the shelf and slope (Brown et al. 2014). The outflow of the Mackenzie River is highly seasonal, with peak outflow and $\mathrm{OM}_{\text {terr }}$ export during the hard-to-sample spring melt and freshet in May/June (Cooper et al. 2005, Raymond et al. 2007). Residence time of $\mathrm{OM}_{\text {terr }}$ in the Beaufort Gyre may be as high as $10 \mathrm{yr}$ (Hansell et al. 2004, Cooper et al. 2005). While sampling efforts in the ice-free season of August-September may underestimate absolute $\mathrm{OM}_{\text {terr }}$ discharge into the system, slow isotopic turnover of Arctic consumer tissue on the order of months (Kaufman et al. 2008, Weems et al. 2012) suggests that including a wide diversity of fauna will facilitate the best characterization of the $\mathrm{OM}_{\text {terr }}$ signal across this region.

Trophic structure is directly affected both by variation in the quality and quantity of primary production entering the base of the food web (Søreide et al. 2006, Bluhm \& Gradinger 2008) as well as by water mass characteristics (Iken et al. 2010). In light of the ongoing and predicted changes in the Beaufort Sea, including decreasing seasonal ice-cover (Frey et al. 2014) and an increase in coastal erosion and terrigenous carbon inputs (Lantuit et al. 2012, Doxaran et al. 2015), elucidating the relative importance of terrestrial- and marine-derived organic matter inputs to the marine food webs will enhance our ability to forecast some biological responses to climate changes.

The objectives of this study were, therefore, to (1) use carbon stable isotopes and $\mathrm{C}: \mathrm{N}$ ratios to identify the relative distribution and biological assimilation of $\mathrm{OM}_{\text {terr }}$ in invertebrate and fish consumers across the Beaufort Sea shelf and slope, and (2) use carbon and nitrogen stable isotopes to analyze variations in the trophic organization of consumers among regions of the Beaufort shelf and slope under varying $\mathrm{OM}_{\text {terr }}$ influence.

\section{MATERIALS AND METHODS}

\section{Study area}

The Beaufort Sea is a seasonally ice-covered and hydrodynamically complex Arctic system, with high riverine inputs onto the shallow shelf waters in the east (Macdonald et al. 1998), the strong influence of productive Chukchi Sea waters to the west of the Beaufort shelf (Okkonen et al. 2009), and deeper Arctic basin water occasionally upwelled along the steep Beaufort slope (Tremblay et al. 2011). The Beaufort shelf is only 80 to $100 \mathrm{~m}$ deep at its abrupt shelf-break 80 to $120 \mathrm{~km}$ offshore, after which the slope can dive to $1000 \mathrm{~m}$ over a horizontal distance of only a few kilometers (Pickart 2004). Over this bathy- 
metric relief, interacting water masses layer vertically (Lansard et al. 2012): freshwater from rivers and sea ice-melt forms a thin surface lens $(0-10 \mathrm{~m})$ over the Pacific-derived polar mixed layer, which can be separated by a pycnocline at around $120 \mathrm{~m}$ water depth from the cold and highly nutrient-rich upper halocline layer. At around $200 \mathrm{~m}$, there is a transition to warmer and more saline Atlantic-derived water, which gradually transitions into the cold Canada Basin deep water below approximately $800 \mathrm{~m}$ depth (Lansard et al. 2012). Each water mass is distinct in temperature, salinity, nutrient concentration, and organic matter composition (Macdonald et al. 1989). Such differences have been linked to variation in food web structure in nearby systems, for example, in the shallow, nearshore Beaufort Sea (Dunton et al. 1989, 2006, 2012), on the Chukchi Sea shelf (Iken et al. 2010), and in the deep Arctic Canada Basin (Iken et al. 2005). Upwelling events related to easterly winds advect nutrients and recycled marine production upwards to the consumers living on the Beaufort shelf (Pickart et al. 2013), while resuspension processes and aggregation mechanisms of biogenic matter can result in a large vertical flux of organic matter from the Beaufort shelf downslope (Forest et al. 2013).

\section{Sampling and at-sea processing}

Samples were collected in the Beaufort Sea aboard the R/V 'Norseman II'. The primary target regions were the central Beaufort Sea in 2012 and the eastern Beaufort Sea in 2013. From 21-30 September 2012, 19 stations along 3 shelf-to-slope transects were sampled between $150^{\circ} \mathrm{W}$ and $151^{\circ} \mathrm{W}$, near the outflow of the Colville River, Alaska (Fig. 1). From 13-31 August 2013, 47 stations were sampled along 6 shelf-slope transects between $136^{\circ} \mathrm{W}$ and $147^{\circ} \mathrm{W}$, spanning the shelf and slope area from the western Mackenzie shelf and trough in Canada to Camden Bay, Alaska (Fig. 1). All transects ran perpendicular to shore and contained between 4 and 9 sampling stations with target bottom depths of 20,37, 50, 100, 200, 350, 500, 750 and $1000 \mathrm{~m}$ (see Table S1 in the Supplement at www. int-res.com/articles/suppl/m550p001_supp.pdf). To best characterize the terrestrial matter distribution and trophic structure in the central and eastern Beaufort Sea, transects were grouped into regions based on the distance to the Mackenzie River and its assumed relative $\mathrm{OM}_{\text {terr }}$ influence (Dunton et al. 2012) (from east to west): Inner Mackenzie Plume (IMP), Outer Mackenzie Plume (OMP), Camden Bay (CB), and Colville Plume (CP) (Fig. 1). The 20, 37, 50, and $100 \mathrm{~m}$ depth

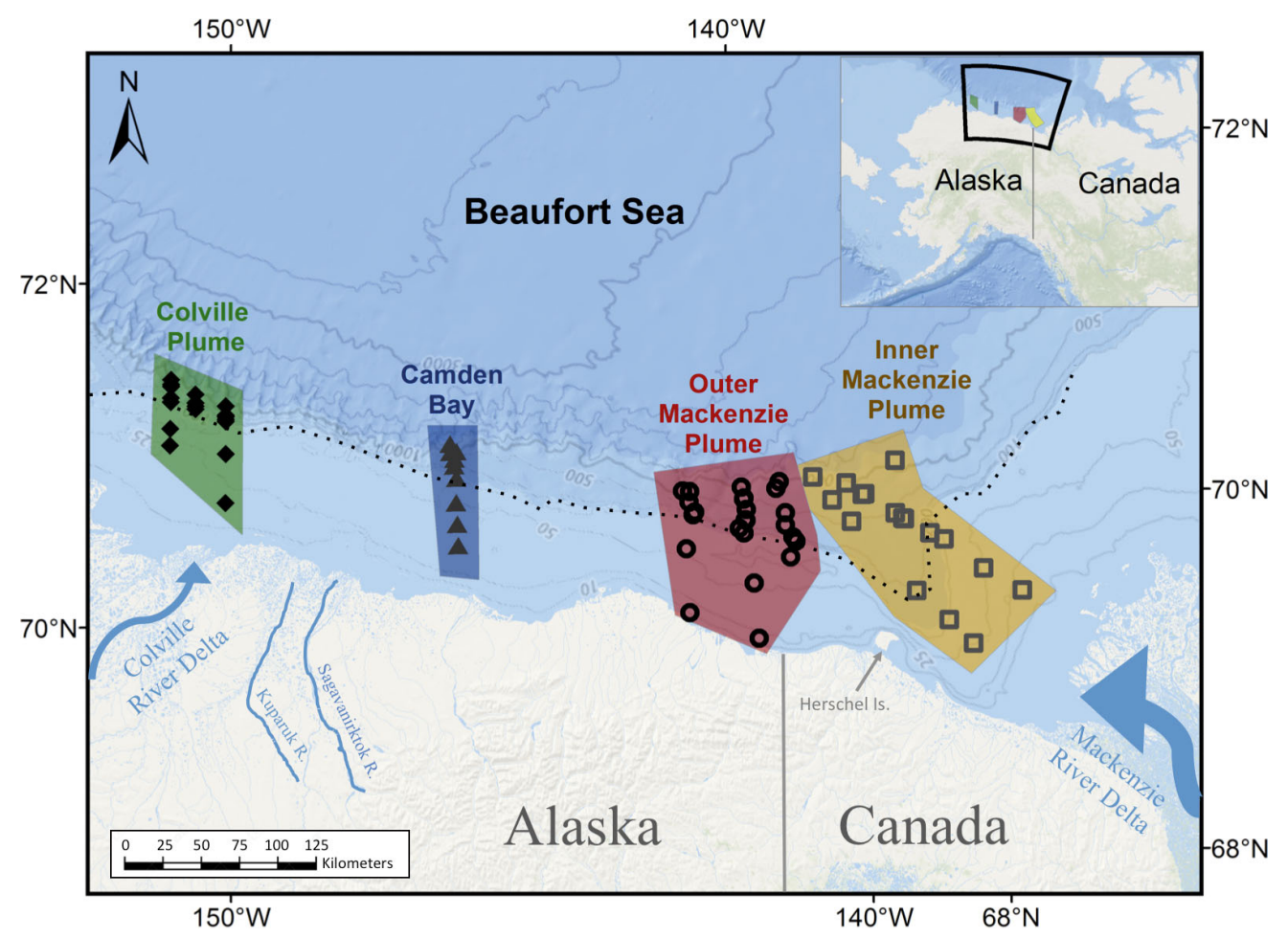

Fig. 1. Stations sampled in the Beaufort Sea. Colville Plume $(\mathrm{CP}, \bullet)$ region stations were sampled in September 2012, while stations in Camden Bay $(\mathrm{CB}, \mathbf{\Delta})$, Outer Mackenzie Plume (OMP, o), and Inner Mackenzie Plume (IMP, 口) regions were sampled in August 2013. Dotted line indicates Beaufort shelf break at approximately $100 \mathrm{~m}$ depth. Ice POM samples were collected from sea ice near Barrow, AK, off-map to the west 
stations per region were grouped as Beaufort 'shelf', while deeper stations were grouped as 'slope'.

To trace the prevalence of Mackenzie Riverderived freshwater across the study area during the time of sampling, surface and $10 \mathrm{~m}$ depth water samples were collected at each station only in 2013 for oxygen stable isotope analysis. Unfiltered water samples from Niskin bottles were pipetted into $2 \mathrm{ml}$ glass vials (Agilent Technologies) with no headspace, crimped closed, and stored at room temperature until analysis. In 2012 and 2013, POM was collected with Niskin bottles from the sub-surface chl a maximum layer, or 20 to $30 \mathrm{~m}$ depth (pPOM; $\mathrm{n}=3$ per station) and from surface sediments (sPOM) from a box core (2012) or van Veen grab (2013) where accessible, to provide baseline stable carbon and nitrogen isotope values for these potential food sources (e.g. Iken et al. 2005, Dunton et al. 2012). Approximately 11 of water for each pPOM replicate was filtered onto a precombusted Whatman GF/F filter (nominal pore size $0.7 \mu \mathrm{m}$ ) and frozen at $-20^{\circ} \mathrm{C}$ until analysis. A single sample of surface sediment POM was taken from the upper $1 \mathrm{~cm}$ at each station where available, and kept frozen until processing. Five sediment samples were taken from a box core near select 2013 slope stations by the Canadian Beaufort Regional Environmental Assessment (BREA) initiative in August and September 2013, as we were unable to sample surface sediments $>200 \mathrm{~m}$ bottom depth in 2013 .

To investigate marine food web structure, representative fauna at each station were collected for isotope analysis. Dominant meso-zooplankton taxa (see Table $1 ; \mathrm{n}=3$ replicate samples per taxon) were collected at each station from $150 \mu \mathrm{m}$ mesh multinet and $505 \mu \mathrm{m}$ mesh bongo net deployments. Replicate $(\mathrm{n}=3)$ samples of major benthic invertebrate taxa were collected from van Veen grabs, box cores, beam trawls (4 mm mesh), and otter trawls (19 mm mesh). Collections from trawls also included demersal fish species. We preferentially collected slow turn-over and mass-dominant tissues in each phylum, specifically muscle, but where unavailable, tissue was derived from tube feet (Asteroidea), oral discs (Ophiuroidea), body wall (Polychaeta, Echiura, Actinaria), and-where insufficient mass was otherwise available-whole individuals (Amphipoda) or pooled individuals (Copepoda, Chaetognatha). When possible, the guts of the whole animals were removed as a precaution against stomach contents influencing isotope analyses, and all tissues were rinsed with filtered seawater. For logistical reasons, tissue samples were kept frozen onboard at $-20^{\circ} \mathrm{C}$ and later dried at $60^{\circ} \mathrm{C}$ for $24 \mathrm{~h}$ onboard (invertebrates) or in the home lab (fishes). Vouchers of invertebrate taxa of uncertain identification were sent to taxonomic experts (see 'Acknowledgments') for species verification. All taxon names were standardized to the World Register of Marine Species (www.marinespecies.org).

Biomass data for epibenthic invertebrate consumers included in the food web analysis were collected concurrently at each station to quantitatively assess biomass distribution within trophic levels. Taxa were quantitatively collected from beam trawl catches, identified on board, and wet weight for each taxon was determined using digital hanging scales. Biomass estimates were calculated from area trawled (= net swath $\times$ haul distance) and normalized to $1000 \mathrm{~m}^{2}$. Beam trawl catches in 2012 (CP region) were deemed non-quantitative and instead we used biomass estimates collected in 2011 from nearby stations with the same method (Ravelo et al. 2015).

Sea ice algae can be an important food source in Arctic systems (McMahon et al. 2006, Roy et al. 2015); however, this study sampled during the ice-free summer period. To include a sea ice algal end member reference value in the trophic mixing models, ice POM (iPOM) was collected off the northwest coast of Barrow, AK at $71.3815^{\circ} \mathrm{N}, 156.5243^{\circ} \mathrm{W}$ on 8 April 2014. Bottom sections of sea ice $(n=2)$ were taken from ice cores, placed in ziploc bags and frozen in the field.

\section{Lab processing and stable isotope analysis}

At the University of Alaska Fairbanks (UAF), pPOM filters were fumed with $\mathrm{HCl}$ vapors for $24 \mathrm{~h}$ to remove carbonate. sPOM samples were repeatedly treated with $1 \mathrm{~N} \mathrm{HCl}$ to remove all carbonates (Iken et al. 2010, Goñi et al. 2013), rinsed until pH stabilized, and freeze-dried. Sea ice samples were thawed and centrifuged to concentrate iPOM ( $\mathrm{n}=3$ replicates per ice piece), and then freeze dried. Tissue samples that contained carbonate were treated with $1 \mathrm{~N} \mathrm{HCl}$ as a precaution against the high variability in $\delta^{13} \mathrm{C}$ values in exoskeleton structures compared to muscle (Yokoyama et al. 2005). Alteration of sample $\delta^{15} \mathrm{~N}$ values due to acidification treatment has been shown to occur for some species and tissues; however, in $79 \%$ of cases this change is $< \pm 1 \%$ (Schlacher \& Connolly 2014). Because lipids can be depleted in ${ }^{13} \mathrm{C}$ relative to protein or carbohydrate and significantly confound stable carbon isotope interpretation in animals with large lipid stores (Mintenbeck et al. 2008), all tissue samples were repeatedly treated with 2:1 chloroform:methanol to remove lipids and re-dried. 
Stable isotope data for all samples were obtained using continuous-flow isotope ratio mass spectrometry (CF-IRMS) at the Alaska Stable Isotope Facility (ASIF) at UAF. Water samples from 2013 were measured for $\delta^{18} \mathrm{O}$ values. All pPOM, sPOM, and iPOM samples and approximately $0.3 \mathrm{mg}$ dry weight of each homogenized faunal tissue sample were analyzed for $\delta^{13} \mathrm{C}$ and $\delta^{15} \mathrm{~N}$ values. $\delta^{18} \mathrm{O}$ values were measured using a pyrolysis-elemental analyzer (ThermoScientific high temperature elemental analyzer - TC/EA) attached via a Conflo IV to an isotope ratio mass spectrometer (IRMS; ThermoFinnigan DeltaV $\left.{ }^{\text {Plus }}\right) . \quad \delta^{13} \mathrm{C}$ and $\delta^{15} \mathrm{~N}$ values were measured using a Costech ESC 4010 elemental analyzer interfaced via a Conflo IV with an IRMS (Thermo Finnigan Delta $\mathrm{V}^{\text {Plus }}$ ). Results are expressed as conventional $\delta$ notation in parts per thousand (\%) according to the following equation:

$$
\delta(\%)=\left(\left[\mathrm{R}_{\text {sample }} / \mathrm{R}_{\text {standard }}\right]-1\right) \times 1000
$$

where $\mathrm{R}$ is the determined ratio of $n\left({ }^{\mathrm{i}} \mathrm{Element}\right) / n\left({ }^{\mathrm{j}} \mathrm{Ele}-\right.$ ment), abbreviated as ${ }^{18} \mathrm{O}:{ }^{16} \mathrm{O},{ }^{13} \mathrm{C}:{ }^{12} \mathrm{C}$, or ${ }^{15} \mathrm{~N}:{ }^{14} \mathrm{~N}$. Standards were Vienna Standard Mean Ocean Water (VSMOW) for $\delta^{18} \mathrm{O}$ values, Vienna Pee Dee Belemnite (VPDB) for $\delta^{13} \mathrm{C}$ values, and atmospheric $\mathrm{N}_{2}$ for $\delta^{15} \mathrm{~N}$ values. Instrument precision at ASIF was $<0.5 \%$ for $\delta^{18} \mathrm{O}$ values, and $<0.2 \%$ for both $\delta^{13} \mathrm{C}$ and $\delta^{15} \mathrm{~N}$ values.

\section{Data analysis: stable isotope values}

Water-mass end members were defined using published $\delta^{18} \mathrm{O}$ values of undiluted samples of these sources. Mackenzie-River-derived freshwater is characterized by a flow-averaged $\delta^{18} \mathrm{O}$ value of $-19.2 \%$ (Cooper et al. 2008). This end member represents a conservative value for river water in this region, as other freshwater contributions from smaller rivers (such as the Colville, Kuparuk, and Sagavanirktok rivers) originate from higher-latitude watersheds and thus are likely to be even more depleted in ${ }^{18} \mathrm{O}$ than Mackenzie-derived freshwater (Cooper et al. 2005). Assuming near-surface $(\leq 20$ $\mathrm{m})$ Beaufort Sea water is a mixture of sea ice melt and the polar mixed layer, the Beaufort Sea oceanwater $\delta^{18} \mathrm{O}$ value has been specified as approximately $-2.3 \%$ (Lansard et al. 2012). Trends in surface and $10 \mathrm{~m}$ depth water $\delta^{18} \mathrm{O}$ values across the study area were visualized in Ocean Data View v.4.5.3 (Schlitzer 2011). For additional verification that water sample $\delta^{18} \mathrm{O}$ values were related to freshwater influence, the correlation between water sample salinity and $\delta^{18} \mathrm{O}$ values at the surface and $10 \mathrm{~m}$ depths was tested using Spearman's rank correlation. Predictive relationships between water $\delta^{18} \mathrm{O}$ values and longitude or log-transformed station bottom depth were tested using regression analyses $(\alpha=0.05)$. Simplified mixing model calculations of percent Mackenzie River water contributions to samples were estimated by comparing $\delta^{18} \mathrm{O}$ values of water samples to the defined $\delta^{18} \mathrm{O}$ values of water source endmembers.

The measured pPOM and sPOM values in this study represent already processed material and were compared with published references for possible POM end members, which included terrestrial POM (mean $\pm \mathrm{SD}: \delta^{13} \mathrm{C}=-28.8 \pm 3.2 \%$, $\delta^{15} \mathrm{~N}=0.8 \pm 1.0 \%$; Schell et al. 1982, Goñi et al. 2000, Dunton et al. 2006), marine phytoplankton POM $\left(\delta^{13} \mathrm{C}=-24.0 \pm\right.$ $0.4 \%, \delta^{15} \mathrm{~N}=7.7 \pm 0.3 \%$, McTigue \& Dunton 2014), and ice POM $\left(\delta^{13} \mathrm{C}=-21.6 \pm 0.5 \%\right.$, $\delta^{15} \mathrm{~N}=8.1 \pm 4.2 \%$, present study). All these published end member values given here are specific to our study region with the exception of the reference value for terrestrial POM, which is not specific to plants within the Mackenzie River watershed, but instead is representative of high-latitude $\mathrm{C}_{3}$ plants throughout the Alaskan and Canadian North Slope. Additionally, though there is high seasonality to the discharge rate of terrestrial POM from the Mackenzie River, relative concentrations of nutrients and organic matter contained in this discharge do not vary substantially throughout the year (Holmes et al. 2012) and, therefore, potential variance in end member isotopic character is considered insignificant in the present study. We were unable to estimate an end member to represent phytoplankton production associated with riverine freshwater, which likely would be isotopically intermediate between marine and terrestrial end members (Goñi et al. 2005). The 3 organic matter sources listed above were used in mixing models using Stable Isotope Analysis in R (SIAR) v.4 (Parnell et al. 2010) to assess their contributions to the pPOM and sPOM samples from this study. While both the Mackenzie River and coastal erosion are distinct vectors of $\mathrm{OM}_{\text {terr }}$ to marine consumers in the Beaufort Sea (Dunton et al. 2006, Casper et al. 2015), these 2 $\mathrm{OM}_{\text {terr }}$ sources were isotopically indistinguishable in this study. pPOM and sPOM $\delta^{13} \mathrm{C}$ and $\delta^{15} \mathrm{~N}$ values were analyzed for significant differences among longitudinal regions and between shelf or slope depthgroups using 2-way analysis of variance (ANOVA, $\alpha=0.05)$, followed by Tukey's post-hoc tests for differences among groups (R 3.0.3; R Development Core Team 2014). 
Given the increase in Arctic ice algal $\delta^{13} \mathrm{C}$ values over the growing season, the early-season snapshot we measured may not fully represent the $\delta^{13} \mathrm{C}$ range of ice algae present in pPOM and sPOM samples. Therefore, we applied the mixing model analysis also with a late spring-bloom situation at high ice algal concentrations $\left(\delta^{13} \mathrm{C}\right.$ value of $-15.5 \%$; Gradinger et al. 2009). This approach allowed us to evaluate how enriched ice algal $\delta^{13} \mathrm{C}$ values would alter the estimates of relative contributions of the various organic matter sources to PPOM and sPOM samples.

To investigate how station bottom depth affected pPOM and sPOM composition, the total organic carbon to total nitrogen (C:N) ratios, and $\delta^{13} \mathrm{C}$ and $\delta^{15} \mathrm{~N}$ values of $\mathrm{pPOM}$ and sPOM samples were correlated with depth within regions. C:N ratios can be an effective proxy for terrestrial organic matter influence, as C:N ratios of terrestrial plants are typically $>15$, whereas phytoplankton C:N ratios range between 4 and 10 (Macdonald et al. 2004).

Not all taxa occurred at all stations, so to maximize food web comparisons among regions and between shelf and slope groupings, taxonomic surrogacy was tested for select species at stations where these species co-occurred, using Student's $t$-tests $(\alpha=0.05)$. If 2 species' isotope values were statistically identical at the same station, these species were grouped at their lowest shared taxonomic level, typically the genus level.

To discern regional differences in carbon source utilization, $\delta^{13} \mathrm{C}$ values of consumers were grouped by feeding guild and analyzed for significant differences between the fixed factors region and depthgroup (shelf or slope), using a 2-way ANOVA ( $\alpha=$ 0.05 ), and then tested for differences between factor groups using Tukey's post-hoc tests. Taxa were assigned to one of 6 feeding guilds: pelagic filter feeders (pFilt, $\mathrm{n}=3$ taxa), pelagic predators (pPred, $\mathrm{n}$ $=2$ ), benthic sub-surface deposit feeders (SSDF, $\mathrm{n}=$ $3)$, benthic surface deposit feeders $(\mathrm{SDF}, \mathrm{n}=9)$, benthic suspension feeders (Sus, $\mathrm{n}=6$ ), and benthic predators or scavengers (Pred, $n=26$ ), based on the literature (see Table 1). The impact of depth on trophic enrichment of $\delta^{15} \mathrm{~N}$ in benthic consumers was tested with regression analysis of the relationship between benthic consumer $\delta^{15} \mathrm{~N}$ value and bottom depth. The majority of taxa did not occur across all depths; thus, only some of the most widespread benthic consumers (snail Colus sabini, sea star Crossaster papposus, brittle star Ophiocten sericeum, polychaete family Polynoidae) were chosen for this analysis.
Particulate organic matter from the upper water column (pPOM) is frequently used as a trophic baseline in the analysis of Arctic marine food webs (e.g. Søreide et al. 2006, Iken et al. 2010). However, recent studies indicate that a depth-stratified approach to defining a baseline is critical when comparing benthic food webs over considerable water depths (Bergmann et al. 2009, Roy et al. 2015). Given the steep bathymetry of the Beaufort slope and the complex hydrodynamic processes of the region (Pickart 2004, Macdonald \& Yu 2006, Hwang et al. 2008), near-surface pPOM does not sink entirely vertically and unprocessed through the water column (Forest et al. 2013) to underlying benthic consumers. The limited number and lack of replicate sPOM samples prevented their use as a reliable, depth-standardized trophic baseline. Instead, the surface deposit-feeding brittle star Ophiocten sericeum, which feeds on freshly sedimented organic matter at the benthos when available (Piepenburg 2000), was chosen as a primary consumer (PC) baseline, providing a longterm integrated signal of utilized food sources at the benthos (Vander Zanden \& Rasmussen 1999, Iken et al. 2010).

Food web length was determined by assuming an average $3.4 \%$ increase in $\delta^{15} \mathrm{~N}$ values per trophic level (TL) (Vander Zanden \& Rasmussen 2001, Post 2002b), consistent with previous Arctic shelf food web research (e.g. Iken et al. 2010, Dunton et al. 2012, McTigue \& Dunton 2014, Roy et al. 2015). The design of our study did not allow for reliable calculation of a scaled trophic enrichment factor framework, which may more accurately represent smaller isotopic fractionation steps with increasing trophic levels (Hussey et al. 2014). The trophic enrichment factor was defined as discrete steps, such as TL 1, TL 2, TL 3, etc., while recognizing the need to conservatively interpret these absolute TL designations. In contrast to distinct TL, the individual trophic position (TP) of each consumer is a continuous variable calculated based on its isotopic distance to a chosen base reference, in this case $O$. sericeum at TL 2. Consumers within each region's shelf and slope food web were standardized to the respective $\delta^{15} \mathrm{~N}$ value of $O$. sericeum from that region and depth-group. Consequently, the $\delta^{15} \mathrm{~N}$ value of the TL 2 baseline for each food web differed based on the varying $\delta^{15} \mathrm{~N}$ values of $O$. sericeum. Consumer trophic positions were calculated from the following equation:

$\mathrm{TP}_{\text {Consumer }}=\left(\left[\delta^{15} \mathrm{~N}_{\text {Consumer }}-\delta^{15} \mathrm{~N}_{\text {O.sericeum }}\right] / 3.4\right)+2$

Biomass data for epibenthic invertebrates from trawl hauls (Ravelo et al. [2015] for 2012 CP region, 
Iken \& Bluhm unpubl. data for all 2013 regions) were used to estimate relative consumer biomass represented within each trophic level in each region and shelf or slope depth-group. Taxon TP was rounded to the next lowest or highest food web TL, for example such that food web TL 3 category included consumers with TP 2.5 to 3.4 , and TL 1 contained all TP $<1.4$. Biomass data were only available for trawled invertebrates and, therefore, only 37 of the 49 taxa included in the full food web analysis could be used for this trophic level comparison. The percentage of total epifaunal biomass represented by the biomassbased TL comparison is provided. To ensure that this subset of taxa represented an equivalent trophic structure to the full set of taxa used in the food web analyses, histograms of number of taxa binned by TL were also compared between the full taxon set and the subset, and were found to be comparable (data not shown).

\section{RESULTS}

\section{Large-scale surface water structure}

Water $\delta^{18} \mathrm{O}$ values from both surface and $10 \mathrm{~m}$ depth were highly correlated with salinity $\left(\mathrm{R}^{2}=0.95\right)$, with slight deviations likely due to isotopic fractionation during ice formation and melt $( \pm 2-3 \%$; Macdonald et al. 1995, Melling \& Moore 1995). Surface water $\delta^{18} \mathrm{O}$ values were lowest $(-12.2 \%$ ) near the Mackenzie River outflow, indicating highest riverine freshwater content, and generally increased with distance from the Mackenzie River delta (Fig. 2A). Grouping all 2013 stations together, neither longitude (as measure of distance from the Mackenzie River) nor position over the Beaufort shelf and slope (approximated by station bottom depth) were significant predictors of surface water $\delta^{18} \mathrm{O}$ values $(\mathrm{p}>0.05)$. However, when grouped by region, station bottom depth was a significant predictor of surface water $\delta^{18} \mathrm{O}$ values $(\mathrm{p}<0.01)$ in both the IMP and OMP regions. Shallower stations were associated with lower surface water $\delta^{18} \mathrm{O}$ values (between -12 and $-10 \%$ ) in the IMP $\left(\mathrm{R}^{2}=0.57\right)$, while they were associated with higher surface water $\delta^{18} \mathrm{O}$ values (between -9 and $-5 \%$ ) in the
OMP $\left(\mathrm{R}^{2}=0.68\right)$. Farther to the west, in the $\mathrm{CB}$ region, there was no relationship between station bottom depth and surface water $\delta^{18} \mathrm{O}$ values, which were around -6 to $-5 \%$ o throughout. At $10 \mathrm{~m}$ depth, the water $\delta^{18} \mathrm{O}$ value isoscape was enriched in oxygen relative to the surface and nearly homogenous (between -6 and $-3 \%$ ) across the eastern Beaufort Sea (Fig. 2B), with no relationship between longitude or station bottom depth at a regional level. Mixing model calculations indicated that Mackenzie River water contributions to surface water samples ranged from $16 \%$ in the CB region to $57 \%$ in the IMP, while $10 \mathrm{~m}$ depth water samples were comprised of 4 to $21 \%$ Mackenzie River-derived water.
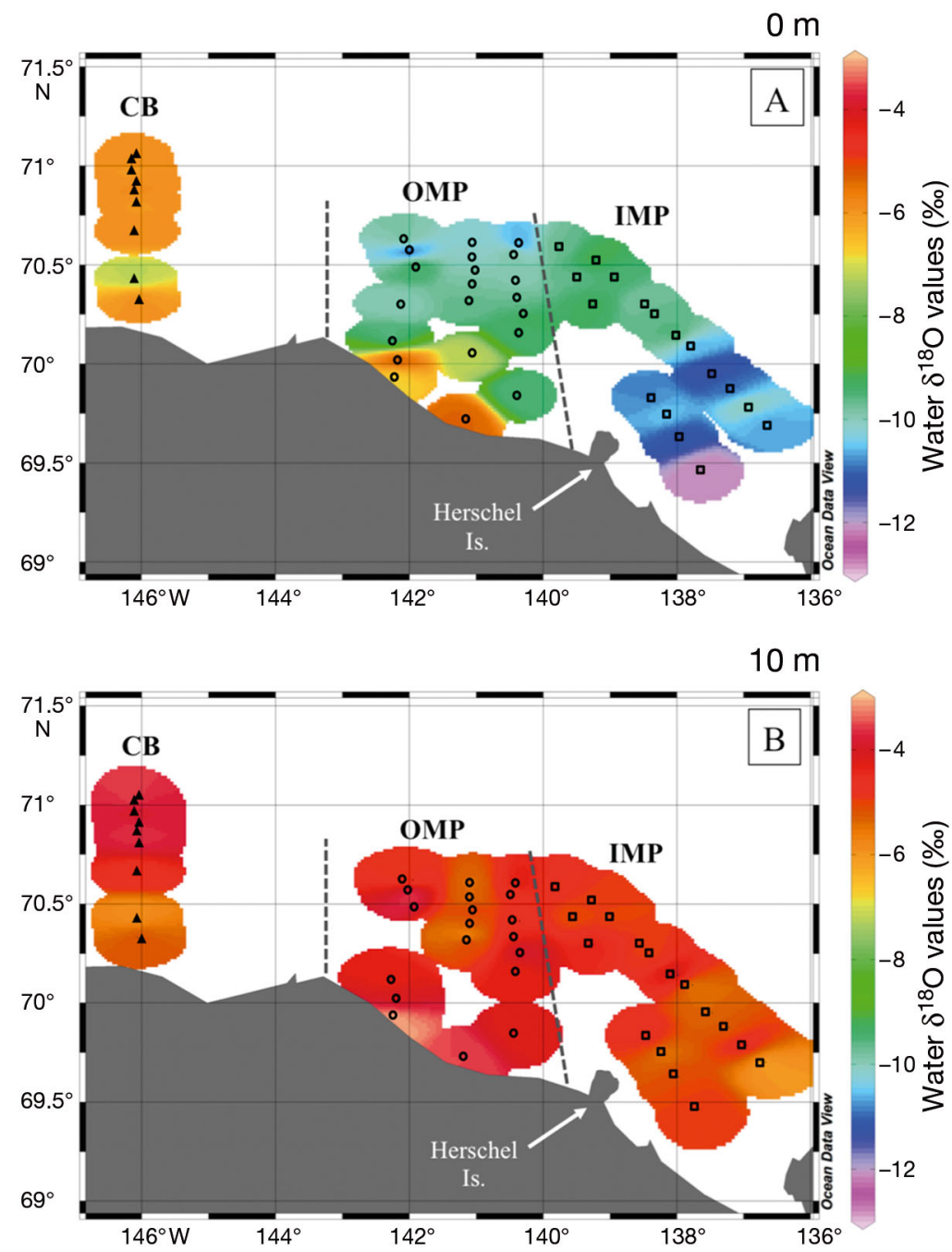

Fig. 2. $\delta^{18} \mathrm{O}$ values (\%) of water samples taken from (A) the surface $(0 \mathrm{~m})$ and (B) $10 \mathrm{~m}$ depth in the 2013 sampling area (CB, OMP, and IMP regions). The Mackenzie River Delta is to the bottom right corner of the maps. Known $\delta^{18} \mathrm{O}$ values of undiluted Mackenzie River and near-surface Beaufort Sea waters in this area are -19.2 (Cooper et al. 2008) and ca. $-2.3 \%$ (Lansard et al. 2012), respectively 


\section{Spatial distribution and influence of terrestrial organic matter}

pPOM and sPOM $\delta^{13} \mathrm{C}$ and $\delta^{15} \mathrm{~N}$ values (Table 1) generally fell in-between published isotopic values of terrestrial and marine organic matter end members, though several samples were outside of the standard deviations of these end members (Fig. 3). Averaged across the entire study area, pPOM was composed of an estimated 58 to $60 \%$ marine-origin $\mathrm{POM}$ and $39 \%$ terrestrial-origin POM, with only 1 to $3 \%$ contribution by ice algal POM (based on our measured April iPOM value and the published May value, both from Barrow). In comparison, sPOM samples consisted of an estimated 33 to $60 \%$ marineorigin POM, 30 to $31 \%$ terrestrial-origin $\mathrm{POM}$, and between 10 to $31 \%$ ice algal POM. Due to the lack of sea ice at our sites at the time of sampling and the high seasonal variability in iPOM reference, we cautiously interpret the estimates of iPOM contributions to our samples. Additionally, because of the minimal impact of iPOM values on range estimates of terrestrial-origin POM contributions to our $\mathrm{pPOM}$ and sPOM samples, for the purposes of our study we have chosen to disregard the $\mathrm{PPOM}$ contributions in our discussion of $\mathrm{OM}_{\text {terr }}$ influence.

The $\mathrm{C}: \mathrm{N}, \delta^{13} \mathrm{C}$, and $\delta^{15} \mathrm{~N}$ ratios of pPOM and sPOM grouped by region had no significant relationship ( $\mathrm{p}$ $>0.05$ ) with bottom depth (Fig. 3), except for sPOM in the IMP region $\left(R^{2}=0.81\right) . \delta^{13} \mathrm{C}$ and $\mathrm{C}: \mathrm{N}$ values were not significantly correlated in either pPOM or sPOM samples. When depth was grouped categorically into shelf versus slope locations, pPOM $\delta^{13} \mathrm{C}$ values were significantly affected by both region and depthgroup (ANOVA, p < 0.05), though the interaction between the fixed factors region and depth-group was not significant. pPOM in the CP region was significantly enriched in ${ }^{13} \mathrm{C}$ compared with more eastern regions over both the shelf and the slope (Fig. 4). In all regions except the IMP, mean pPOM $\delta^{13} \mathrm{C}$ values were higher on the shelf relative to the slope; however, these differences were not significant because of high within-region variation. sPOM $\delta^{13} \mathrm{C}$ values were significantly lower on the shelf versus slope in the $\mathrm{CP}$ and IMP regions, but were not significantly different elsewhere (Fig. 4). sPOM $\delta^{13} \mathrm{C}$ values were not well correlated with pPOM $\delta^{13} \mathrm{C}$ values sampled at the same stations $\left(\mathrm{R}^{2}=0.16\right) . \delta^{15} \mathrm{~N}$ values of pPOM and sPOM were not significantly different between shelf and slope stations across or within regions (not shown).

Mean $\delta^{13} \mathrm{C}$ values of consumers (Table 1) grouped by feeding guild generally decreased when moving eastward from the CP to the IMP region, though the statistical significance of these trends depended on feeding guild and region (Fig. 4). $\delta^{13} \mathrm{C}$ values of pelagic filter feeders ( $\mathrm{pFilt}$ ) and pelagic predators (pPred) in the CP region were significantly (ANOVA, $\mathrm{p}<0.001$ ) higher compared with these pelagic consumers in all other regions for both shelf and slope depth-groups. Benthic predators (Pred) in both the $\mathrm{CP}$ and $\mathrm{CB}$ regions were significantly (ANOVA, $\mathrm{p}<$ 0.001) enriched in ${ }^{13} \mathrm{C}$ compared with predators on the IMP shelf and the OMP and IMP slope. Regional trends in $\delta^{13} \mathrm{C}$ values for benthic sub-surface (SSDF), surface deposit feeders (SDF), and suspension feeders (Sus) were not significant. Within-region differences between the shelf and slope did not show a consistent pattern across feeding guilds (Fig. 4).

\section{Regional and depth variation in food web structure}

$\delta^{15} \mathrm{~N}$ values of a selection of the most widespread consumers (Colus sabini, Crossaster papposus, Ophiocten sericeum, Polynoidae) from across the study area had significant $(\mathrm{p}<0.001)$ positive relationships with bottom depth $\left(\mathrm{R}^{2}\right.$ range $\left.=0.45-0.66\right)$ with an increase in $\delta^{15} \mathrm{~N}$ values on the order of 2 to $5 \%$ from 20 to $1000 \mathrm{~m}$ depth (Fig. 5). This overall trend of increasing $\delta^{15} \mathrm{~N}$ ratios with depth was observed for the majority of benthic taxa and feeding guilds (Table 1), but could not be statistically confirmed for less widespread taxa. There also appeared to be a trend of increased sPOM $\delta^{15} \mathrm{~N}$ values with bottom depth in the IMP and OMP regions (Fig. 3), though statistical power to verify this trend was too low due to lack of deep sediment samples and sample replicates.

Food web structure standardized to the $\delta^{15} \mathrm{~N}$ value of primary consumer $O$. sericeum equalling TL 2 (Fig. 6) differed slightly among regions and between the shelf and the slope within regions. The $\mathrm{CP}$ region shelf food web was approximately 0.7 to $1.7 \mathrm{TL}$ shorter than the food webs on the shelves of the more eastern regions. The CP slope food web was also shorter than the OMP and IMP slope regions by more than 0.5 TL. Many of the consumer taxa present within TL 1 of the $\mathrm{CP}$ region food webs were also present in the other regions, where they occupied higher TPs than the TL 2 represented by the primary consumer $O$. sericeum. Consequently, the longer food webs in the $\mathrm{CB}$, OMP, and IMP regions were accompanied by an apparent trophic gap between the primary consumer $O$. sericeum and other consumers, excluding the cumaceans Diastylis spp. that had extremely low TP in all regions. Food web struc- 


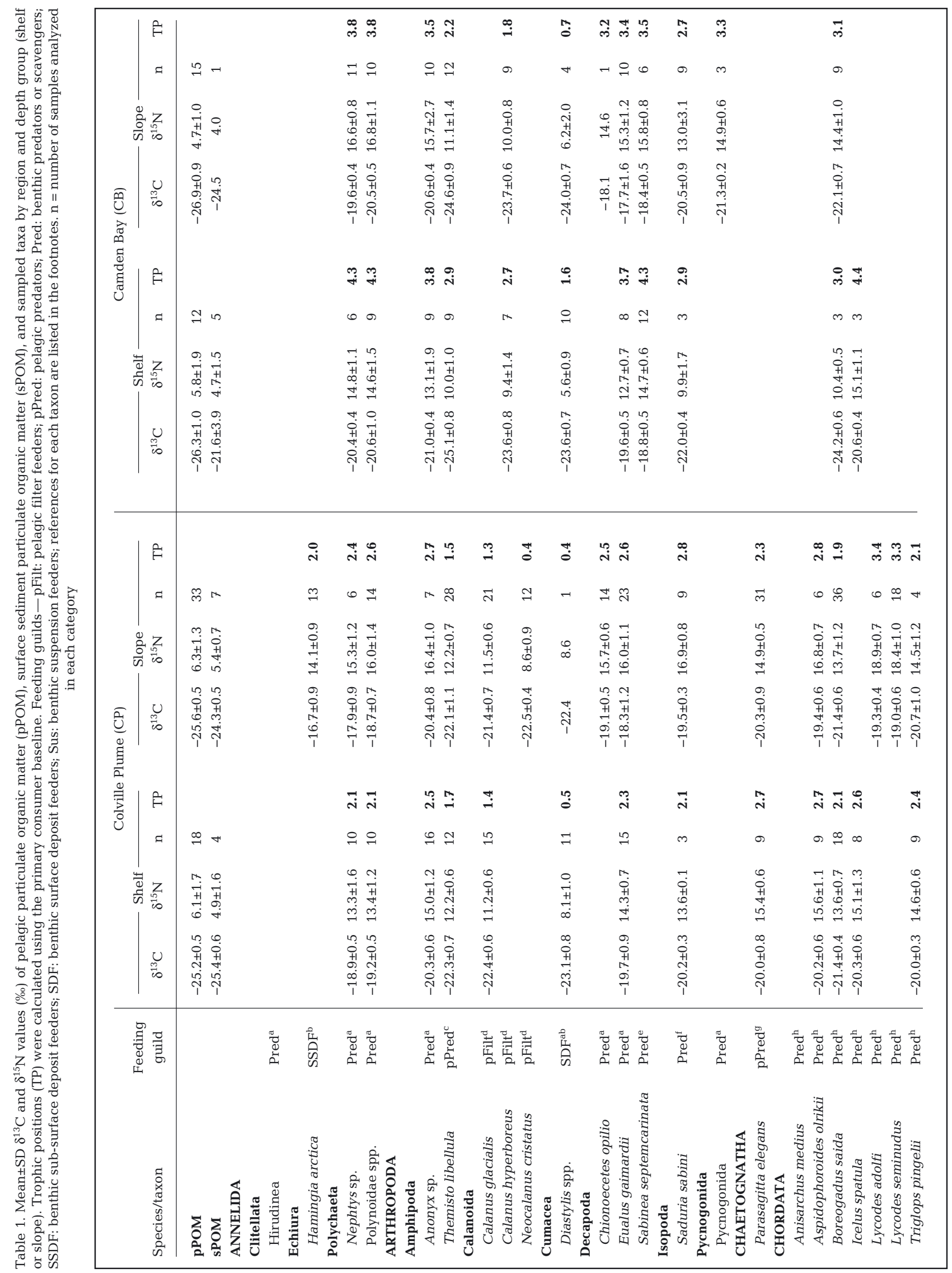




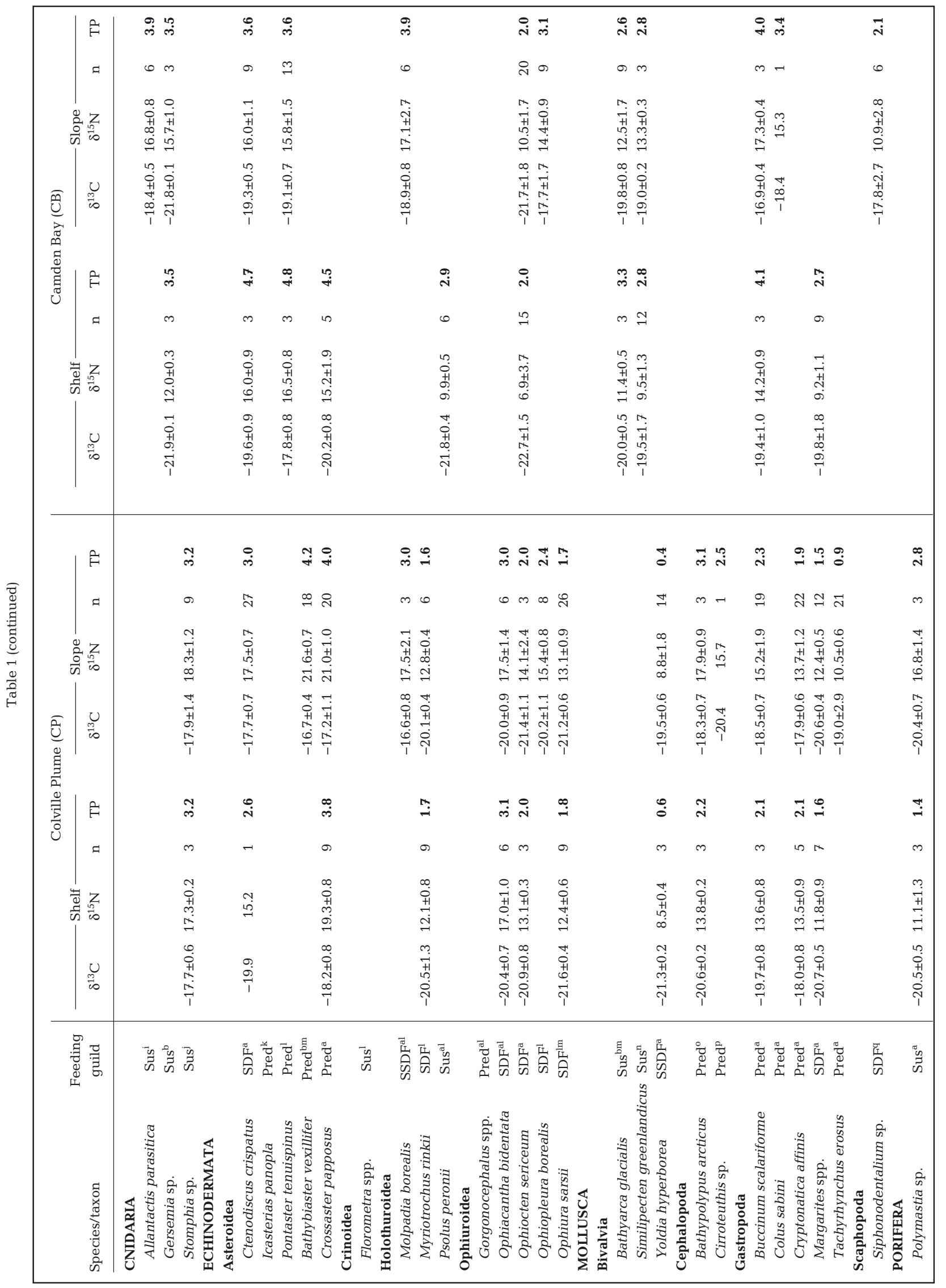




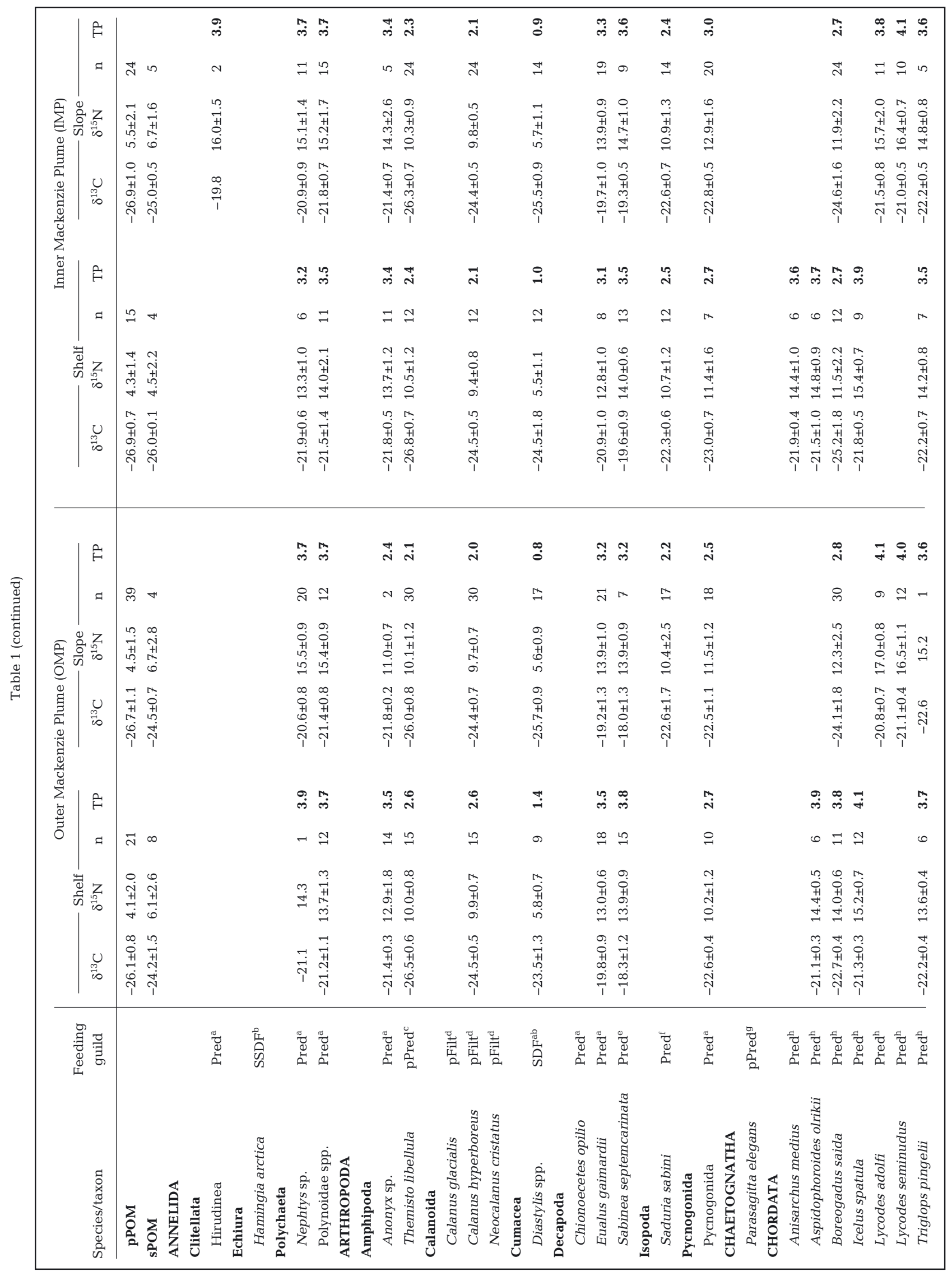




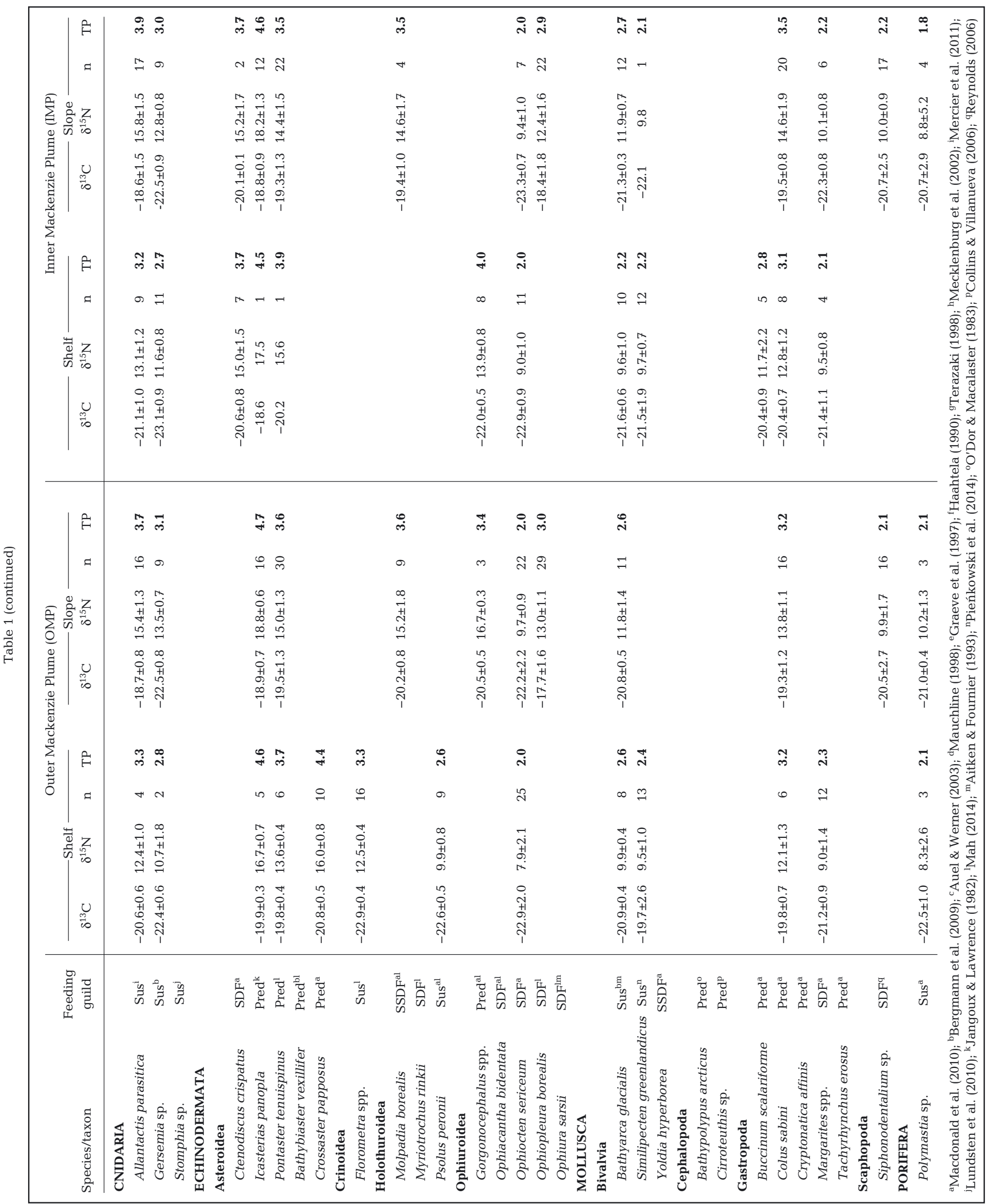




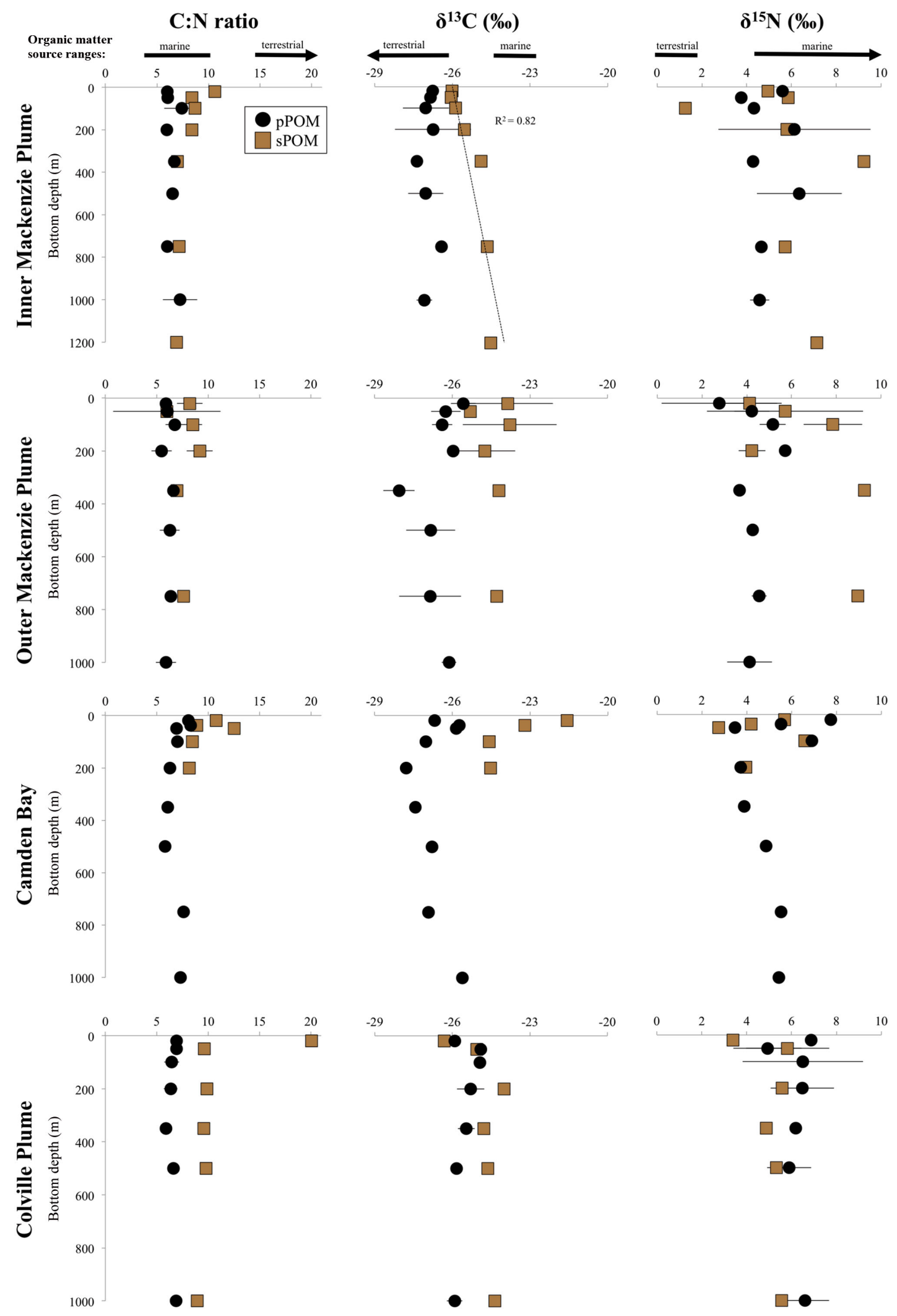

Fig. 3. Carbon to nitrogen ratios, $\delta^{13} \mathrm{C}$ and $\delta^{15} \mathrm{~N}$ values of $\mathrm{pPOM}$ and sPOM with station bottom depth, averaged by region. Error bars indicate SD between replicates across transects, and trend lines and $\mathrm{R}^{2}$ values are only shown for significant relationships between organic matter tracer and station bottom depth. Arrows and lines above the $x$-axis indicate typical value ranges for terrestrial and marine organic matter based on published literature 


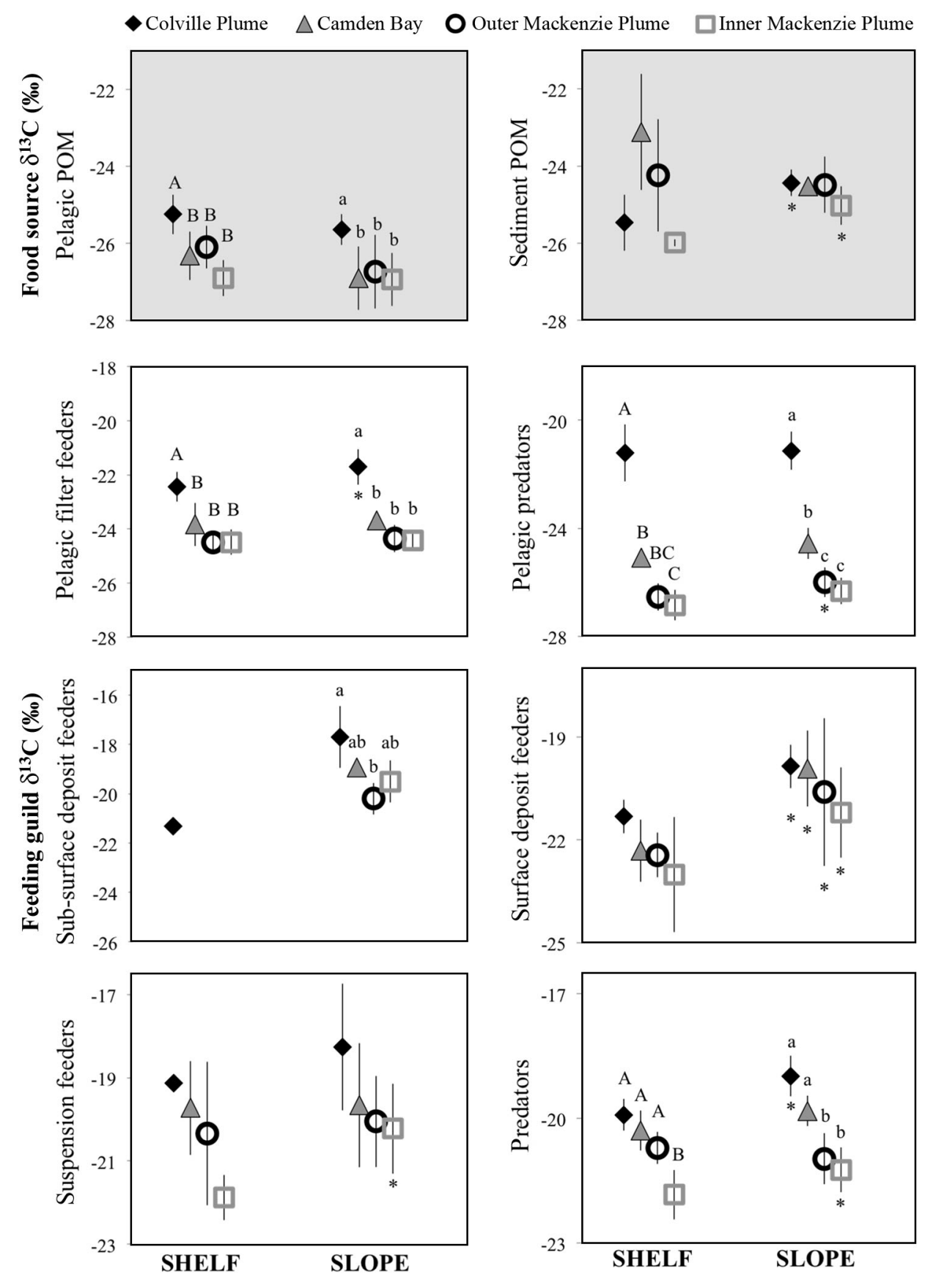

Fig. 4. Mean $( \pm \mathrm{SD}) \delta^{13} \mathrm{C}$ values $(\%)$ of possible food sources (particulate organic matter, POM; shaded background) and consumer feeding guilds (white background), by region and depth-group (shelf or slope). Different letters denote significantly different groupings among regions, comparing shelf (upper case letters) and slope (lower case letters) depth-groups separately. Asterisks $\left({ }^{*}\right)$ denote significant differences between shelf versus slope depth-groups within the same region. Note that the $\delta^{13} \mathrm{C}$ scale differs between panels

tures across shelf and slope depth-groups were very similar to one another in the IMP and OMP regions.

The relative distribution of epibenthic consumer biomass by trophic levels differed among regional food webs (Fig. 7). Within each region, shelf food webs had a much higher proportion of biomass contained in TL 2 than in corresponding slope food webs, regardless of number of species represented per TL. CP region shelf and slope food webs both had a significantly higher proportion of biomass in TLs 1 and 2 than all other regions, with TLs 1 and 2 com- posing $94 \%$ of biomass on the CP shelf and $41 \%$ of biomass on the $\mathrm{CP}$ slope. In contrast, in $\mathrm{CB}$, OMP, and IMP regions, consumers at TL 3 to 5 represented the majority of biomass, accounting for 70 to $79 \%$ of biomass in shelf food webs and 91 to $96 \%$ of biomass in slope food webs. Species included in biomass calculations by trophic level accounted for 54 to $88 \%$ of the total biomass at each region. Low biomass representation on the OMP and IMP shelves resulted from limited sampling of dominant taxa for stable isotopes at some stations in these locations. 


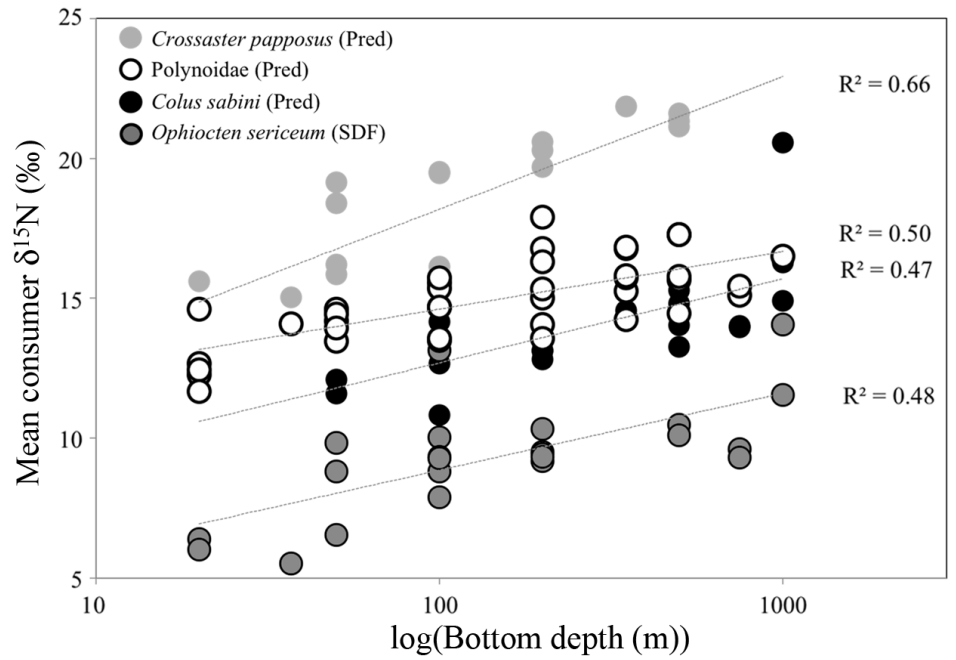

Fig. 5. $\delta^{15} \mathrm{~N}$ values (\%) by bottom depth on log-scale for select benthic consumers across all regions. Each point represents the replicate mean $\delta^{15} \mathrm{~N}$ value of a consumer at one station. All trends were significant; linear regression trend lines are shown with respective $\mathrm{R}^{2}$ values

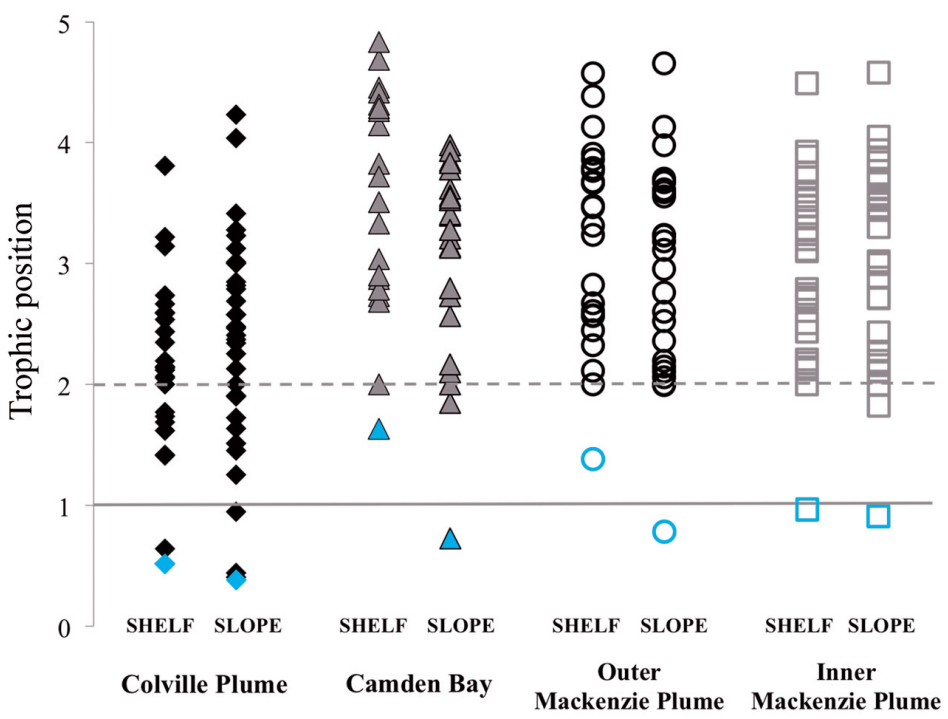

Fig. 6. Trophic positions (TP) of all consumers by shelf and slope regions. Food webs are built using the primary consumer Ophiocten sericeum $\delta^{15} \mathrm{~N}$ value $=$ trophic level (TL) 2, shown with the dashed line. The solid line shows the assumed TL of the organic matter end member supporting each food web, and is not a measured value. Blue symbols represent the TP of the cumacean Diastylis spp. The relative absence of taxa with TPs between TL 1 and 2 in CB, OMP, and IMP food webs is referred to as the 'trophic gap'

\section{DISCUSSION}

\section{Freshwater and terrestrial matter distribution and utilization}

Surface water $\delta^{18} \mathrm{O}$ values in the upper $5 \mathrm{~m}$ (Fig. 2) across the eastern Beaufort Sea suggested the influ- ence of Mackenzie Plume waters westward of the Mackenzie Delta, and did not indicate substantial freshwater influence from other outflow sources in this area, such as the Sagavanirktok River near Camden Bay. The Coriolis force typically directs the Mackenzie Plume to the east of the river delta; however, the plume at the surface of an Ekman layer can react rapidly to easterly wind stress, which can drive the Mackenzie-derived waters offshore and to the west (Macdonald \& Yu 2006, Mulligan et al. 2010). As would be expected, the freshwater signal as indicated by $\delta^{18} \mathrm{O}$ values was strongest near the immediate outflow of the river and became diluted farther offshore over the Beaufort slope. In contrast, to the west of Herschel Island, the freshwater signal was strongest offshore and weak nearshore. These trends may be explained by an easterly wind regime: easterly winds $>5 \mathrm{~m} \mathrm{~s}^{-1}$ at nearby Tuktoyaktuk, Northwest Territory, Canada, were sustained for the $48 \mathrm{~h}$ immediately preceding our sampling in the Mackenzie region (OMP and IMP) (The Weather Underground, Inc.), which are favorable conditions for upwelling on the Beaufort shelf (Williams et al. 2006). Under such conditions, the associated Ekman transport of the Mackenzie surface plume would follow a northerly track offshore perpendicular to the coast (i.e. nearly parallel to IMP transects), while marine water upwelled over the shelf-break forced by isobath divergence near Herschel Island would reach the surface waters in the nearshore OMP (Macdonald \& Yu 2006, Williams et al. 2006). There, Herschel Island acts to divert westward-flowing Mackenzie plume surface water away from the coast, allowing a pocket of upwelled water to remain close to shore (Macdonald \& Yu 2006, Williams et al. 2006). The relatively colder and more saline water observed at the surface in the nearshore OMP compared to nearshore surface waters of all other regions supports the presence of upwelling in this region at the time of sampling. The absence of any distinct freshwater signal in water sampled from $10 \mathrm{~m}$ depth indicates that, when present, freshwater was confined to a thin surface layer in the Beaufort Sea.

Contrasting with the observed gradients in Beaufort Sea surface waters associated with the Mackenzie River plume, the relative proportion of $\mathrm{OM}_{\text {terr }}$ versus marine organic matter influence in pPOM 


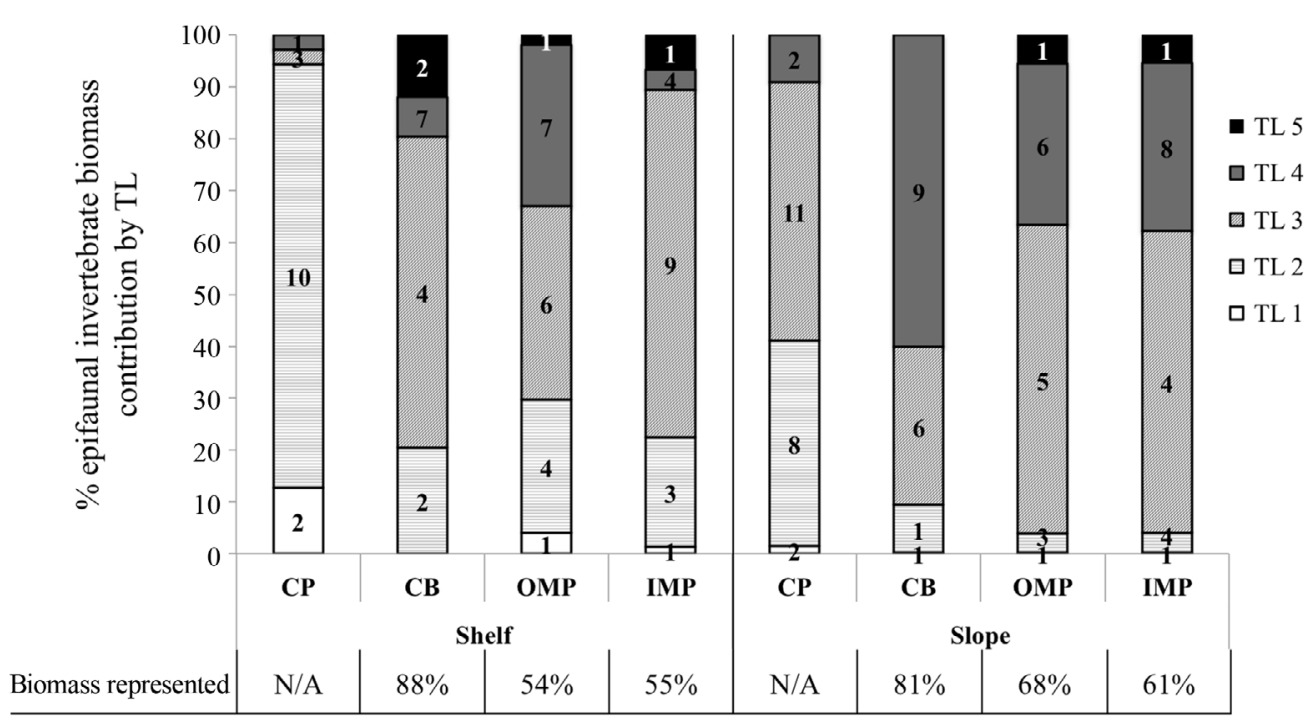

Fig. 7. Relative biomass of consumers within each trophic level (TL) based on using a primary consumer baseline (see Fig. 6), by shelf and slope regions. Histogram labels indicate the number of taxa included in each bar section. Due to some mismatches between available biomass and isotope data from the same stations, these data represent a subset of all taxa included in the food web analyses. Percent of total mean biomass represented by the taxa in this figure are indicated. CP region biomass estimates were acquired from data collected during a different project in 2011 (Ravelo et al. 2015), separate from this study's sampling effort, and could thus not be directly matched with this study's isotope samples (indicated by N/A). Regions: $\mathrm{CP}$-Colville Plume, CB_Camden Bay, OMP_Outer Mackenzie Plume, IMP_Inner Mackenzie Plume

samples did not differ in nearshore and offshore surface waters (Fig. 3). Instead, over the 3 more eastern regions of our study area (CB, OMP, IMP), $\delta^{13} \mathrm{C}$ values of pPOM indicated a relatively high $\mathrm{OM}_{\text {terr }}$ influence across both the Beaufort shelf (also found by Divine et al. 2015) and slope. This finding may indicate that $\mathrm{OM}_{\text {terr }}$ initially entrained within the Mackenzie surface plume is at some point disassociated from freshwater plume by sinking out and is advected with other water masses, reaching lateral distances greater than the plume freshwater reaches, as earlier studies also suggest (Forest et al. 2007, 2013, Goñi et al. 2000). In addition, our data may be evidence that other vectors of $\mathrm{OM}_{\text {terr }}$ (e.g. coastal erosion, smaller rivers) contributed significantly to the proportion of $\mathrm{OM}_{\text {terr }}$ present in pPOM samples at Beaufort shelf and slope stations at the time of our sampling. Considering that all surface water samples were sufficiently depleted in ${ }^{18} \mathrm{O}$ to suggest some degree of mixing between Mackenzie Plume freshwater and Beaufort Sea ocean water, it was not surprising that many sPOM $\delta^{13} \mathrm{C}$ values and $\delta^{15} \mathrm{~N}$ values of pPOM and SPOM fell somewhere in between the isotopic ranges of terrestrial and marine organic matter end members. In addition, large vertical and horizontal POM flux (Forest et al. 2013) from upwelling events (Williams et al. 2006), bottom resuspension (Forest et al. 2007), and lateral advection (Hwang et al. 2008) can mix the terrestrial versus marine contri- butions to pPOM and sPOM (Goñi et al. 2000, Divine et al. 2015).

The relatively low C:N values ( $<10$ for $82 \%$ of POM samples) across the study area do not indicate strong $\mathrm{OM}_{\text {terr }}$ influence and mixing, contrary to the high surface sediment C:N values characteristic of terrestrial plants found in prior studies across the eastern Beaufort Sea (Goñi et al. 2000, Goñi et al. 2013). This inconsistency may be due to our comparatively laterseason sampling effort, and highlights the temporal susceptibility of organic matter composition in this region. Though isotope values and C: $\mathrm{N}$ ratios for the $\mathrm{OM}_{\text {terr }}$ end member are likely to remain relatively consistent throughout the year (Holmes et al. 2012), both C:N ratios of Mackenzie River-derived $\mathrm{OM}_{\text {terr }}$ and the proportion of Mackenzie River-derived $\mathrm{OM}_{\text {terr }}$ versus marine production available to marine consumers change seasonally (Goñi et al. 2000, Macdonald \& Yu 2006). Further, pPOM, sPOM, and organism tissue integrate these temporal changes on different timescales. The C:N values of POM samples in this study (Fig. 3) may allude to this effect: samples of transitory pPOM across the Beaufort Sea fall wholly within the marine end member range, while samples of relatively stable sPOM are higher, perhaps indicating greater $\mathrm{OM}_{\text {terr }}$ influence over a longer time scale. These results indicate the necessity of a sampling methodology that captures a variety of temporal scales for sufficient consideration of marine 
trophic dynamics in this region of complex organic matter source and flux.

The regional distribution of $\mathrm{pPOM}$ and $\mathrm{sPOM} \delta^{13} \mathrm{C}$ values provided a spatial perspective of relative carbon source differences along and across the shelf and slope (Fig. 4), though the following processes make the interpretation challenging. First, estuarine phytoplankton associated with Arctic river freshwater has been hypothesized to be more depleted in ${ }^{13} \mathrm{C}$ than marine phytoplankton (Goñi et al. 2005), and yet may provide a more labile food source to marine consumers than the isotopically similar but more recalcitrant land-derived $\mathrm{OM}_{\text {terr }}$. We were unable to isotopically separate inputs from freshwater algal production from marine and terrestrial end members, and thus could not specifically account for organic matter contributions from estuarine phytoplankton in this study. Second, particle-associated microbial processing of $\mathrm{OM}_{\text {terr }}$ entering the Beaufort Sea from the Mackenzie River is a very important component of organic matter processing in this region (OrtegaRetuerta et al. 2012, Rontani et al. 2014). The microbial breakdown of $\mathrm{OM}_{\text {terr }}$ can result in an increase in both $\delta^{13} \mathrm{C}$ and $\delta^{15} \mathrm{~N}$ values of the $\mathrm{OM}_{\text {terr }}$ of $>5 \%$ (Macko \& Estep 1984), which consequently may become less isotopically distinct from marine production. Thus, pPOM and sPOM data should be interpreted assuming some degree of isotopic transformation accompanying microbial processing of pPOM during its transit to the bottom of the Beaufort shelf and slope (Macko \& Estep 1984) as opposed to direct mixing between untransformed organic matter sources. Unfortunately, lacking precise knowledge of the ${ }^{13} \mathrm{C}$ and ${ }^{15} \mathrm{~N}$ fractionation factors associated with microbial processing (Lehmann et al. 2002 and references therein), it is difficult to estimate the degree to which this activity may disguise the influence of $\mathrm{OM}_{\text {terr }}$ via isotope enrichment. Lastly, the contributions of iPOM to our pPOM and SPOM samples also may not be well approximated. The $\delta^{13} \mathrm{C}$ value ascribed to the iPOM end member was much lower than known for peak ice algal bloom conditions (see 'Materials and methods: Data analysis: stable isotope values'), resulting in a possible overestimate of iPOM contributions in the mixing models. An overestimation is likely given that no sea ice was encountered during this study's late-summer sampling efforts, and that the majority of Arctic ice-associated production is either consumed rapidly within 7 to $20 \mathrm{~d}$ after deposition at the seafloor (McMahon et al. 2006, Sun et al. 2007), or else composes only a small fraction of the long-term pool of sediment organic matter (North et al. 2014).
Regardless of these mixing model limitations, significant ${ }^{13} \mathrm{C}$ enrichment of pPOM in the western Beaufort Sea study region indicates relatively higher marine production inputs to the western compared with the eastern study area. Pelagic consumer isotope values in the western Beaufort $\mathrm{CP}$ region paralleled the marine-derived pPOM $\delta^{13} \mathrm{C}$ values relative to pelagic taxa in all other regions, suggesting direct utilization of marine production from the water column. The higher contribution of marine production in $\mathrm{CP}$ region pelagic consumer tissues may derive both from local inputs as well as supplementary inputs of marine production advected into the western Beaufort Sea from the Chukchi Sea (Okkonen et al. 2009). Combined with an obvious (although not always significant) trend of overall ${ }^{13} \mathrm{C}$ enrichment from eastern to western study regions on both the shelf and the slope in all feeding guilds, these data support a transition in main food source from more of the ${ }^{13} \mathrm{C}$-depleted $\mathrm{OM}_{\text {terr }}$ in the east to more of the ${ }^{13} \mathrm{C}$ enriched marine production in the west. Extensive literature supports this gradient of increasing $\mathrm{OM}_{\text {terr }}$ across the Beaufort shelf with proximity to the Mackenzie River in nearshore benthic and shelf zooplankton communities and in sediments (e.g. Dunton et al. 1989, Goñi et al. 2000), corroborating the trend seen in this study in $\delta^{13} \mathrm{C}$ values of pPOM and consumer tissues in shelf and slope benthos.

Within the benthos, $\delta^{13} \mathrm{C}$ patterns of surface deposit feeders and suspension feeders mirrored regional $\delta^{13} \mathrm{C}$ patterns in pPOM but were also enriched in ${ }^{13} \mathrm{C}$ compared to pPOM $(+4-5 \%$ for SDF and $+5-7 \%$ for Sus). This observed ${ }^{13} \mathrm{C}$ enrichment between pelagic and benthic components substantiates similar trends previously reported in the Bering Sea (Lovvorn et al. 2005), Chukchi Sea (McTigue et al. 2015), and nearshore Beaufort Sea (Dunton et al. 2006) that have been interpreted as evidence of microbial activity in these regions. Accordingly, some degree of microbial modification of organic matter occurred in all regions of our study area, regardless of terrestrial influence. However, compared to the CP region, in the more eastern $\mathrm{CB}$, OMP, and IMP regions SPOM was substantially more enriched in ${ }^{13} \mathrm{C}$ from pPOM, which could be accounted for by a greater degree of microbial reworking during transit to the benthos in regions of enhanced $\mathrm{OM}_{\text {terr }}$ influence. These isotopic trends support findings that pelagic bacterial abundance and production in the eastern Beaufort Sea decrease away from the Mackenzie River outflow (Ortega-Retuerta et al. 2012), and indicate the unique substrate that $\mathrm{OM}_{\text {terr }}$ may provide for microbial communities in marine systems. 


\section{Trophic structure by depth and terrestrial matter influence}

Shorter food webs in the western Beaufort CP region imply that trophic coupling between basal food sources and consumers was tighter in the west, where pPOM $\delta^{13} \mathrm{C}$ values also indicated marine production was present in higher proportion compared with more eastern Beaufort regions (see previous section). Farther east, a gap in the food web between the assumed TP of the organic matter food source and the measured TPs of consumers suggests recurrent isotopic fractionation caused by heightened microbial breakdown of organic matter (Fig. 6). The only sampled taxa consistently found within this 'trophic gap' were the cumaceans Diastylis spp., categorized as surface deposit feeders but whose extremely low trophic positions in multiple food web studies suggest they may fractionate differently or feed on labile food sources not accounted for by these studies (Iken et al. 2005, Bergmann et al. 2009). $\mathrm{OM}_{\text {terr }}$ is largely composed of complex structural materials from vascular plants, such as cellulose and xylan, thus it can be difficult for marine primary consumers to assimilate directly as they lack the necessary digestive enzymes (Tenore 1983 and references therein). Microbial decomposition of $\mathrm{OM}_{\text {terr }}$ can effectively break down these complex structures, making a higher proportion of the energy available in $\mathrm{OM}_{\text {terr }}$ to then be utilized (possibly combined with the microbial colonizers) as a food source by other marine consumers (Garneau et al. 2009). The presence of this trophic gap in the terrestrially influenced regional food webs of this study substantiates the critical role of the microbial loop in connecting $\mathrm{OM}_{\text {terr }}$ to marine consumers in the eastern Beaufort Sea (Vallières et al. 2008, Garneau et al. 2009, Rontani et al. 2014). We think it is unlikely that unsampled plankton or epifauna taxa occupy this gap, as the majority of taxa that occupied the gap region $(1<\mathrm{TP}$ $<2$ ) in the food webs of the western, marine-influenced CP region also occurred farther east, but there were displaced to higher trophic positions. Our use of $O$. sericeum as a food web baseline at TL 2 , while an unconventional basis for calculating the trophic position of pelagic consumers, effectively defines the relative trophic relationship between pelagic and benthic components of each regional food web. The pelagic and benthic taxa at $\mathrm{TP}<2$ in the $\mathrm{CP}$ region may represent the consumers most responsible for high pelagic-benthic coupling in productive areas by feeding on the fresh inputs of marine-origin OM. In contrast, where pelagic-benthic coupling is re- duced, such as nearer to the Mackenzie River outflow, surface deposit feeders such as $O$. sericeum may replace those consumers as the first to incorporate the prevalent microbially modified $\mathrm{OM}_{\text {terr }}$ food source.

The observed general increase in consumer $\delta^{15} \mathrm{~N}$ values with increasing bottom depth may also be related to microbial processing (Mintenbeck et al. 2007, Robinson et al. 2012), because bacterial degradation and remineralization processes are functions of water depth, or sinking time of surface organic material (Macko \& Estep 1984, Robinson et al. 2012). Such processes result in a marked increase in $\delta^{15} \mathrm{~N}$ values with depth in POM (Altabet \& Francois 2001) that may be $>10 \%$ from 0 to $1000 \mathrm{~m}$ (Mintenbeck et al. 2007), indicative of increasingly degraded organic matter. Vertical fluxes of particulates over the Beaufort Sea shelf break (100-200 m depth) peaked in the month of August in 2009, with mass fluxes around 300-600 mg (dry weight) $\mathrm{m}^{-2} \mathrm{~d}^{-1}$ at locations near to the Mackenzie River (Forest et al. 2013). Bacterial activity is positively associated with overall magnitude of vertical particle flux (Forest et al. 2013), thereby providing a conduit of $\mathrm{OM}_{\text {terr }}$ to depth as pelagic microbial processing degrades and assimilates organic matter present in the water column (Ortega-Retuerta et al. 2012, Kellogg \& Deming 2014). These activities may also influence $\delta^{13} \mathrm{C}$ values of food sources during sinking, as evidenced by the non-significant trend of ${ }^{13} \mathrm{C}$ enrichment in consumers found at slope depths $(>200 \mathrm{~m})$ compared to consumers on the shelf within the same feeding guild (Fig. 5).

We consider the trend in the benthic consumers $\delta^{15} \mathrm{~N}$ values with bottom depth unlikely to originate from differences in the relative proportion of $\mathrm{OM}_{\text {terr }}$ being utilized as a food source at different depths. Fresh $\mathrm{OM}_{\text {terr }}$ is depleted in ${ }^{15} \mathrm{~N}$ by approximately $6 \%$ compared with marine-derived matter (Dunton et al. 2006, McTigue \& Dunton 2014), so an increase in organic matter $\delta^{15} \mathrm{~N}$ values would be anticipated when moving from nearshore regions with greater influence of $\mathrm{OM}_{\text {terr }}$ to offshore regions with higher inputs of marine production. However, neither pPOM nor $\mathrm{SPOM} \delta^{15} \mathrm{~N}$ values revealed a gradient of decreasing $\mathrm{OM}_{\text {terr }}$ influence moving away from shore over the Beaufort slope. Regardless of the cause, the consistent trend of consumer tissue ${ }^{15} \mathrm{~N}$ enrichment with depth demonstrates the importance of using a depth-normalized approach to food web analysis (Roy et al. 2015) to correct for variables related to station bottom depth, and their effect on stable isotope values. In this study, the use of the $\delta^{15} \mathrm{~N}$ value of the benthic primary consumer $O$. sericeum as a food web 
baseline normalized shelf and slope food web lengths, correcting for any systematic depth-related variable effects on food web length.

A similarly increasing trend with depth, as observed for $\delta^{15} \mathrm{~N}$, would also be expected for $\delta^{13} \mathrm{C}$ values of SPOM and benthic consumers if relative terrestrial versus marine endmember contributions were primarily responsible for driving depth-related trends in carbon isotope values (e.g. Dunton et al. 2006, Casper et al. 2015). However, $\delta^{13} \mathrm{C}$ data showed few significant differences between the composition of pPOM, sPOM and consumers on the shelf versus the slope. Compared to the significant differences in $\delta^{13} \mathrm{C}$ values of benthic consumers across regions with highly varying $\mathrm{OM}_{\text {terr }}$ influence, the differences between consumer $\delta^{13} \mathrm{C}$ values on the shelf and slope are relatively minor and thus unlikely to be similarly driven by a change in proportional $\mathrm{OM}_{\text {terr }}$ utilization. For the few regions and feeding guilds showing some depth-related enrichment in ${ }^{13} \mathrm{C}$ on the slope relative to the shelf, it is possible that this reflected a small but significant enrichment in ${ }^{13} \mathrm{C}$ with trophic level (Vander Zanden \& Rasmussen 2001), as would occur during microbial metabolism during organic matter sinking.

The similarity of shelf and slope carbon sources and food web structure close to the Mackenzie River speaks to the strong influence of $\mathrm{OM}_{\text {terr }}$ in this region. Furthermore, considering the high seasonality of both particulate (Forest et al. 2015) and dissolved (Cooper et al. 2005, Raymond et al. 2007, Holmes et al. 2012) fractions of $\mathrm{OM}_{\text {terr }}$ input from rivers into the Beaufort Sea, the late summer sampling dates of this study mean that our results are likely an underestimate of the potential contributions of terrestrial organic matter to marine food webs in these areas. The transport and advection of $\mathrm{OM}_{\text {terr }}$ from the Mackenzie River down the Beaufort slope (Goñi et al. 2000) may be facilitated by the morphology of the Beaufort Sea's relatively narrow shelf and steep slope compared to the broad shelves of the Eurasian Arctic, frequent upwelling and resuspension processes (Forest et al. 2013), and vertical convection of brine-enriched waters from sea ice melt (Dittmar 2004). The equivalent lengths of shelf and slope food webs in the regions near the Mackenzie River indicate that the trophic effect of $\mathrm{OM}_{\text {terr }}$ appears to be equally important on the eastern Beaufort shelf and slope regardless of water depth or the differing benthic community composition (Nephin et al. 2014). These findings imply that the microbial communities responsible for processing $\mathrm{OM}_{\text {terr }}$ at deep locations on the Beaufort slope may have a similar function to the microbial loop of the Arctic deep-sea in terms of the reworking of any available refractory organic matter sources (Findlay et al. 2015) prior to consumption by metazoan fauna (Gontikaki et al. 2011).

In all regions where the food web was characterized by a gap at low trophic levels, large proportions of epifaunal biomass were represented by higher trophic levels on both shelf and slope. We suggest this pattern is a consequence of these regions receiving greater amounts of terrestrial production, necessitating an additional trophic step due to microbial reworking of this energy source. Conversely, in the western Beaufort CP region, greater inputs of marine production caused shorter food webs dominated by proportionally more epifaunal biomass at lower trophic levels.

\section{CONCLUSIONS}

The interplay of high inputs of $\mathrm{OM}_{\text {terr }}$ into the Beaufort Sea from Canada's Mackenzie River with advected and in situ marine primary production drives variation in marine trophic structure across the Beaufort shelf and slope. Stable isotope analyses of surface water, particulate organic matter, and pelagic and benthic consumers from locations ranging from 20 to $1000 \mathrm{~m}$ bottom depth revealed a strong isotopic imprint of $\mathrm{OM}_{\text {terr }}$ in the eastern Beaufort Sea, which decreased westward from the Mackenzie River. Concurrent with high $\mathrm{OM}_{\text {terr }}$ influence, shelf and slope food webs in the eastern Beaufort Sea were characterized by increased food web length and a greater proportion of epibenthic macro-consumer biomass at higher trophic levels compared with western Beaufort Sea food webs. We suggest that microbial processing is the underlying process explaining this pattern. Although the total primary production available to marine consumers in the highly $\mathrm{OM}_{\text {terr-influenced }}$ eastern Beaufort Sea is lower than in the western regions of the Pacific Arctic (Sakshaug 2004), microbially processed $\mathrm{OM}_{\text {terr }}$ may to some extent compensate for reduced amounts of fresh algal food sources. Well-developed microbial communities specifically associated with terrestrial matter in the Beaufort Sea have high efficiency of metabolic $\mathrm{OM}_{\text {terr }}$ turnover even under low temperature conditions (Vallières et al. 2008, Garneau et al. 2009, Ortega-Retuerta et al. 2012, Rontani et al. 2014). Our results, therefore, challenge the paradigm that $\mathrm{OM}_{\text {terr }}$ is an unusable or a poor food source for marine consumers (e.g. Schell 1983, Berglund et al. 2007), and instead suggest that the unique substrate that $\mathrm{OM}_{\text {terr }}$ provides for ensuing 
microbial activity may be essential to the formation of a relatively high-quality food source.

With warming climate, the role of $\mathrm{OM}_{\text {terr }}$ and its microbial processing may increase in the Arctic in the future, given that zooplankton biomass and biological processes such as fish growth and total food web efficiency can be positively correlated with terrestrially associated microbial production when temperature is simultaneously increased (Lefébure et al. 2013). In addition, we suggest that terrestrially derived energetic support for Arctic marine consumers likely has increasingly significant relevance for marine communities in a time of increased river runoff and coastal erosion inputs into the Arctic Ocean (Holmes et al. 2013, Doxaran et al. 2015). An adaptive microbial loop that expands its activity and production in response to increased $\mathrm{OM}_{\text {terr }}$ contributions in the Beaufort Sea (as suggested by OrtegaRetuerta et al. 2012) would not only facilitate the regeneration of dissolved terrestrially derived nutrients to be utilized in marine primary production (Tank et al. 2012), but could also enable an efficient pathway for $\mathrm{OM}_{\text {terr }}$ to function as a complementary food source for marine consumers (Lefébure et al. 2013). Given the dynamic and synergistic effects of climate change already being observed in Arctic ecosystems (Wassmann et al. 2011), our ability to make informed predictions of the impacts of shifting organic matter sources in the Beaufort Sea will be critical to understanding ongoing effects of anthropogenic and environmental drivers on the functioning of Arctic marine food webs.

Acknowledgments. The authors thank the Captains and crews of the R/V 'Norseman II' for their invaluable support in the field. This work was conducted under BOEM Cooperative Agreement No. M12AC00011 'US-Canada Transboundary Fish and Lower Trophic Communities', U.S. Department of the Interior, Bureau of Ocean Energy Management (BOEM), Alaska Outer Continental Shelf Region, Anchorage, Alaska as part of the BOEM Environmental Studies Program. We gratefully acknowledge the support of project PI Dr. B. Norcross (UAF) and BOEM program manager K. Wedemeyer. This research was supported in part by a UAF Center for Global Change Student Research Grant with funds from the Cooperative Institute for Alaska Research. This study would not have been possible without the help of N. Haubenstock and T. Howe at the Alaska Stable Isotope Facility, who assisted us with the analysis of our large number of isotope samples. We are indebted to the international team of taxonomists who offered their time and expertise in invertebrate identification in support of our work: A. Brandt, L. Cole, K. Coyle, N. Foster, S. Gerken, G. Hendler, M. Hoberg, E. Jorgensen, M. Kedra, P. Kuklinski, C. Mah, R. Melzer, E. Rodriguez, and A. Rogacheva. We thank S. McPhee for collecting additional sediment samples during the 2013 BREA study field season aboard the 'Frosti'.
The manuscript greatly benefited from discussion with $\mathrm{M}$. Wooller and S. Okkonen (UAF). All samples collected for this study were treated under the guidelines of the Institutional Animal Care and Use Committee and under IACUC protocol no.134765.

\section{LITERATURE CITED}

Abrams PA, Roth JD (1994) The effects of enrichment of three-species food chains with nonlinear functional responses. Ecology 75:1118-1130

Aitken AE, Fournier J (1993) Macrobenthos communities of Cambridge, McBeth and Itirbilung Fiords, Baffin Island, Northwest Territories, Canada. Arctic 46:60-71

Altabet MA, Francois R (2001) Nitrogen isotope biogeochemistry of the Antarctic Polar Frontal Zone at $170^{\circ} \mathrm{W}$. Deep-Sea Res II 48:4247-4273

Arim M, Marquet PA, Jaksic FM (2007) On the relationship between productivity and food chain length at different ecological levels. Am Nat 169:62-72

Auel H, Werner I (2003) Feeding, respiration and life history of the hyperiid amphipod Themisto libellula in the Arctic marginal ice zone of the Greenland Sea. J Exp Mar Biol Ecol 296:183-197

Berglund J, Müren U, Båmstedt U, Andersson A (2007) Efficiency of a phytoplankton-based and a bacteria-based food web in a pelagic marine system. Limnol Oceanogr 52:121-131

Bergmann M, Dannheim J, Bauerfeind E, Klages M (2009) Trophic relationships along a bathymetric gradient at the deep-sea observatory HAUSGARTEN. Deep-Sea Res I 56:408-424

Bluhm BA, Gradinger R (2008) Regional variability in food availability for Arctic marine mammals. Ecol Appl 18: S77-S96

Brown KA, McLaughlin F, Tortell PD, Varela DE, Yamamoto-Kawai M, Hunt B, Francois R (2014) Determination of particulate organic carbon sources to the surface mixed layer of the Canada Basin, Arctic Ocean. J Geophys Res C Oceans 119:1084-1102

> Casper AF, Rautio M, Martineau C, Vincent WF (2015) Variation and assimilation of Arctic riverine seston in the pelagic food web of the Mackenzie River Delta and Beaufort Sea transition zone. Estuaries Coasts 38:1656-1663

Collins MA, Villanueva R (2006) Taxonomy, ecology and behaviour of the cirrate octopods. Oceanogr Mar Biol Annu Rev 44:277-322

> Connelly TL, McClelland JW, Crump BC, Kellogg CTE, Dunton KH (2015) Seasonal changes in quantity and composition of suspended particulate organic matter in lagoons of the Alaskan Beaufort Sea. Mar Ecol Prog Ser 527:31-45

> Cooper LW, Benner R, McClelland JW, Peterson BJ and others (2005) Linkages among runoff, dissolved organic carbon, and the stable oxygen isotope composition of seawater and other water mass indicators in the Arctic Ocean. J Geophys Res 110:G02013, doi:10.1029/2005 jg000031

> Cooper LW, McClelland JW, Holmes RM, Raymond PA, Gibson J, Guay CK, Peterson BJ (2008) Flow-weighted values of runoff tracers $\left(\delta^{18} \mathrm{O}, \mathrm{DOC}, \mathrm{Ba}\right.$, alkalinity) from the six largest Arctic rivers. Geophys Res Lett 35:L18606, doi: 10.1029/2008GL035007

> Dittmar T (2004) Evidence for terrigenous dissolved organic nitrogen in the Arctic deep sea. Limnol Oceanogr 49: 148-156 
Divine LM, Iken K, Bluhm BA (2015) Regional benthic food web structure on the Alaskan Beaufort Sea shelf. Mar Ecol Prog Ser 531:15-32

Dunton KH, Saupe SM, Golikov AN, Schell DM, Schonberg SV (1989) Trophic relationships and isotope gradients among Arctic marine fauna. Mar Ecol Prog Ser 56:89-97

> Dunton KH, Goodall JL, Schonberg SV, Grebmeier JM, Maidment DR (2005) Multi-decadal synthesis of benthic-pelagic coupling in the western Arctic: role of crossshelf advective processes. Deep-Sea Res II 52:3462-3477

> Dunton KH, Weingartner T, Carmack EC (2006) The nearshore western Beaufort Sea ecosystem: circulation and importance of terrestrial carbon in Arctic coastal food webs. Prog Oceanogr 71:362-378

> Dunton KH, Schonberg SV, Cooper LW (2012) Food web structure of the Alaskan nearshore shelf and estuarine lagoons of the Beaufort Sea. Estuaries Coasts 35:416-435

> Doxaran D, Devred E, Babin M (2015) A $50 \%$ increase in the amount of terrestrial particles delivered by the Mackenzie River into the Beaufort Sea (Canadian Arctic Ocean) over the last 10 years. Biogeosciences 12:3551-3565

Emmerton CA, Lesack LFW, Vincent WF (2008) Nutrient and organic matter patterns across the Mackenzie River estuary and shelf during the seasonal recession of seaice. J Mar Syst 74:741-755

Findlay H, Gibson G, K dra M, Morata N and others (2015) Responses in Arctic marine carbon cycle processes: conceptual scenarios and implications for ecosystem function. Polar Res 34:24252

Forest A, Sampei M, Hattori H, Makabe R and others (2007) Particulate organic carbon fluxes on the slope of the Mackenzie Shelf (Beaufort Sea): physical and biological forcing of shelf-basin exchanges. J Mar Syst 68:39-54

$>$ Forest A, Babin M, Stemmann L, Picheral M and others (2013) Ecosystem function and particle flux dynamics across the Mackenzie Shelf (Beaufort Sea, Arctic Ocean): an integrative analysis of spatial variability and biophysical forcings. Biogeosciences 10:2833-2866

Forest A, Osborne PD, Fortier L, Sampei M, Lowings MG (2015) Physical forcings and intense shelf-slope fluxes of particulate matter in the halocline waters of the Canadian Beaufort Sea during winter. Cont Shelf Res 101: $1-21$

Frey KE, Maslanik JA, Kinney JC, Maslowski W (2014) Recent variability in sea ice cover, age, and thickness in the Pacific Arctic region. In: Grebmeier JM, Maslowski W (eds) The Pacific Arctic region: ecosystem status and trends in a rapidly changing environment. Springer, Dordrecht, p 31-63

> Garneau MÉ, Vincent WF, Terrado R, Lovejoy C (2009) Importance of particle-associated bacterial heterotrophy in a coastal Arctic ecosystem. J Mar Syst 75:185-197

Gat JR (1996) Oxygen and hydrogen isotopes in the hydrologic cycle. Annu Rev Earth Planet Sci 24:225-262

Goñi MA, Yunker MB, Macdonald RW, Eglinton TI (2000) Distribution and sources of organic biomarkers in Arctic sediments from the Mackenzie River and Beaufort Shelf. Mar Chem 71:23-51

Goñi MA, Yunker MB, Macdonald RW, Eglinton TI (2005) The supply and preservation of ancient and modern components of organic carbon in the Canadian Beaufort Shelf of the Arctic Ocean. Mar Chem 93:53-73

Goñi MA, O'Connor AE, Kuzyk ZZ, Yunker MB, Gobeil C, Macdonald RW (2013) Distribution and sources of organic matter in surface marine sediments across the North American Arctic margin. J Geophys Res C Oceans 118:4017-4035
Gontikaki E, van Oevelen D, Soetaert K, Witte U (2011) Food web flows through a sub-arctic deep-sea benthic community. Prog Oceanogr 91:245-259

Gradinger RR, Kaufman MR, Bluhm BA (2009) Pivotal role of sea ice sediments in the seasonal development of nearshore Arctic fast ice biota. Mar Ecol Prog Ser 394:49-63

> Graeve M, Kattner G, Piepenburg D (1997) Lipids in Arctic benthos: Does the fatty acid and alcohol composition reflect feeding and trophic interactions? Polar Biol 18: 53-61

Haahtela I (1990) What do Baltic studies tell us about the isopod Saduria entomon (L.)? Ann Zool Fenn 27:269-278

- Hansell DA, Kadko D, Bates NR (2004) Degradation of terrigenous dissolved organic carbon in the western Arctic Ocean. Science 304:858-861

> Holmes RM, McClelland JW, Peterson BJ, Tank SE and others (2012) Seasonal and annual fluxes of nutrients and organic matter from large rivers to the Arctic Ocean and surrounding seas. Estuaries Coasts 35:369-382

Holmes RM, Coe MT, Fiske GJ, Gurtovaya $\mathrm{T}$ and others (2013) Climate change impacts on the hydrology and biogeochemistry of Arctic rivers. In: Goldman CR, Kumagai M, Robarts RD (eds) Climatic change and global warming of inland waters: impacts and mitigation for ecosystems and societies. John Wiley \& Sons, Oxford, p 3-26

> Hussey NE, MacNeil MA, McMeans BC, Olin JA and others (2014) Rescaling the trophic structure of marine food webs. Ecol Lett 17:239-250

Hwang J, Eglinton TI, Krishfield RA, Manganini SJ, Honjo S (2008) Lateral organic carbon supply to the deep Canada Basin. Geophys Res Lett 35:L11607, doi:10.1029/ 2008GL034271

> Iken K, Bluhm BA, Gradinger R (2005) Food web structure in the high Arctic Canada Basin: evidence from $\delta^{13} \mathrm{C}$ and $\delta^{15} \mathrm{~N}$ analysis. Polar Biol 28:238-249

Iken K, Bluhm B, Dunton K (2010) Benthic food-web structure under differing water mass properties in the southern Chukchi Sea. Deep-Sea Res II 57:71-85

Jangoux M, Lawrence JM (1982) Echinoderm nutrition. CRC Press, Rotterdam

> Kaufman MR, Gradinger RR, Bluhm BA, O'Brien DM (2008) Using stable isotopes to assess carbon and nitrogen turnover in the Arctic sympagic amphipod Onisimus litoralis. Oecologia 158:11-22

Kellogg CTE, Deming JW (2014) Particle-associated extracellular enzyme activity and bacterial community composition across the Canadian Arctic Ocean. FEMS Microbiol Ecol 89:360-375

Klein Breteler WCM, Schogt N, Baas M, Schouten S, Kraay GW (1999) Trophic upgrading of food quality by protozoans enhancing copepod growth: role of essential lipids. Mar Biol 135:191-198

> Lansard B, Mucci A, Miller LA, Macdonald RW, Gratton Y (2012) Seasonal variability of water mass distribution in the southeastern Beaufort Sea determined by total alkalinity and $\delta^{18} \mathrm{O}$. J Geophys Res C Oceans 117:C03003 doi:10.1029/2011JC007299

> Lantuit H, Overduin PP, Couture N, Wetterich S and others (2012) The Arctic coastal dynamics database: a new classification scheme and statistics on Arctic permafrost coastlines. Estuaries Coasts 35:383-400

> Lefébure R, Degerman R, Andersson A, Larsson S, Eriksson LO, Båmstedt U, Byström P (2013) Impacts of elevated terrestrial nutrient loads and temperature on pelagic food-web efficiency and fish production. Glob Change Biol 19:1358-1372 
Lehmann MF, Bernasconi SM, Barbieri A, McKenzie JA (2002) Preservation of organic matter and alteration of its carbon and nitrogen isotope composition during simulated and in situ early sedimentary diagenesis. Geochim Cosmochim Acta 66:3573-3584

Lovvorn JR, Cooper LW, Brooks ML, De Ruyck CC, Bump JK, Grebmeier JM (2005) Organic matter pathways to zooplankton and benthos under pack ice in late winter and open water in late summer in the north-central Bering Sea. Mar Ecol Prog Ser 291:135-150

Lundsten L, Paull CK, Schlining KL, McGann M, Ussler W III (2010) Biological characterization of a whale-fall near Vancouver Island, British Columbia, Canada. Deep-Sea Res I 57:918-922

Macdonald RW, Carmack EC, McLaughlin FA, Iseki K, Macdonald DM, O'Brien MC (1989) Composition and modification of water masses in the Mackenzie Shelf estuary. J Geophys Res 94(C12):18057-18070

Macdonald RW, Paton DW, Carmack EC, Omstedt A (1995) The freshwater budget and under-ice spreading of Mackenzie River Water in the Canadian Beaufort Sea based on salinity and ${ }^{18} \mathrm{O} /{ }^{16} \mathrm{O}$ measurements in water and ice. J Geophys Res C Oceans 100(C1):895-919, doi: 10.1029/94JC02700

- Macdonald RW, Solomon SM, Cranston RE, Welch HE, Yunker MB, Gobeil C (1998) A sediment and organic carbon budget for the Canadian Beaufort Shelf. Mar Geol 144:255-273

Macdonald RW, Falkner KK, Swift JH (1999) Connections among ice, runoff and atmospheric forcing in the Beaufort Gyre. Geophys Res Lett 26:2223-2226

Macdonald RW, Naidu AS, Yunker MB, Gobeil C (2004) The Beaufort Sea: distribution, sources, fluxes, and burial rates of organic carbon. In: Stein R, Macdonald RW (eds) The organic carbon cycle in the Arctic Ocean. Springer, Heidelberg, p 177-192

Macdonald RW, Yu Y (2006) The Mackenzie estuary of the Arctic Ocean. Handb Environ Chem 5:91-120

Macdonald TA, Burd BJ, Macdonald VI, van Roodselaar A (2010) Taxonomic and feeding guild classification for the marine benthic macroinvertebrates of the Strait of Georgia, British Columbia. Can Tech Rep Fish Aquat Sci 2874

Macko SA, Estep MLF (1984) Microbial alteration of stable nitrogen and carbon isotopic compositions of organic matter. Org Geochem 6:787-790

Mah CL (2014) World Asteroidea Database. www.marinespecies.org (accessed 14 Nov 2014)

Mauchline J (1998) The biology of calanoid copepods. Advances in Marine Biology, 33. Academic Press, San Diego

McClelland JW, Townsend-Small A, Holmes RM, Pan F, Stieglitz M, Khosh M, Peterson BJ (2014) River export of nutrients and organic matter from the North Slope of Alaska to the Beaufort Sea. Water Resour Res 50: 1823-1839

McMahon KW, Ambrose WG Jr, Johnson BJ, Sun MY, Lopez GR, Clough LM, Carroll ML (2006) Benthic community response to ice algae and phytoplankton in Ny Ålesund, Svalbard. Mar Ecol Prog Ser 310:1-14

McTigue ND, Dunton KH (2014) Trophodynamics and organic matter assimilation pathways in the northeast Chukchi Sea, Alaska. Deep-Sea Res II 102:84-96

McTigue ND, Bucolo P, Liu Z, Dunton K (2015) Pelagicbenthic coupling, food webs, and organic matter degradation in the Chukchi Sea: insights from sedimentary pigments and stable carbon isotopes. Limnol Oceanogr 60:429-445
Mecklenburg CW, Mecklenburg TA, Thorsteinson LK (2002) Fishes of Alaska. American Fisheries Society, Bethesda

Melling H, Moore RM (1995) Modification of halocline source waters during freezing on the Beaufort Sea shelf: evidence from oxygen isotopes and dissolved nutrients. Cont Shelf Res 15:89-113

Mercier A, Schofield M, Hamel JF (2011) Evidence of dietary feedback in a facultative association between deep-sea gastropods and sea anemones. J Exp Mar Biol Ecol 396:207-215

Mintenbeck K, Jacob U, Knust R, Arntz WE, Brey T (2007) Depth-dependence in stable isotope ratio $\delta^{15} \mathrm{~N}$ of benthic POM consumers: the role of particle dynamics and organism trophic guild. Deep-Sea Res I 54:1015-1023

- Mintenbeck K, Brey T, Jacob U, Knust R, Struck U (2008) How to account for the lipid effect on carbon stable-isotope ratio $\left(\delta^{13} \mathrm{C}\right)$ : sample treatment effects and model bias. J Fish Biol 72:815-830

Mulligan RP, Perrie W, Solomon S (2010) Dynamics of the Mackenzie River plume on the inner Beaufort shelf during an open water period in summer. Estuar Coast Shelf Sci 89:214-220

- Naidu AS, Scalan RS, Feder HM, Goering JJ and others (1993) Stable organic carbon isotopes in sediments of the north Bering-south Chukchi seas, Alaskan-Soviet Arctic Shelf. Cont Shelf Res 13:669-691

Nephin J, Juniper SK, Archambault P (2014) Diversity, abundance and community structure of benthic macroand megafauna on the Beaufort shelf and slope. PLoS ONE 9:e101556

North CA, Lovvorn JR, Kolts JM, Brooks ML, Cooper LW, Grebmeier JM (2014) Deposit-feeder diets in the Bering Sea: potential effects of climatic loss of sea ice-related microalgal blooms. Ecol Appl 24:1525-1542

O'Dor RK, Macalaster EG (1983) Bathypolypus arcticus. In: Boyle PR (ed) Cephalopod life cycles, Vol. 1. Academic Press, London, p 401-410

Okkonen SR, Ashjian CJ, Campbell RG, Maslowski W, Clement-Kinney JL, Potter R (2009) Intrusion of warm Bering/Chukchi waters onto the shelf in the western Beaufort Sea. J Geophys Res C Oceans 114:C00A11 doi: 10.1029/2008JC004870

Ortega-Retuerta E, Jeffrey W, Babin M, Bélanger S and others (2012) Carbon fluxes in the Canadian Arctic: patterns and drivers of bacterial abundance, production and respiration on the Beaufort Sea margin. Biogeosciences 9: 3679-3692

Parnell AC, Inger R, Bearhop S, Jackson AL (2010) Source partitioning using stable isotopes: coping with too much variation. PLoS One 5:e9672

Pickart RS (2004) Shelfbreak circulation in the Alaskan Beaufort Sea: mean structure and variability. J Geophys Res 109:C04024

Pickart RS, Spall MA, Mathis JT (2013) Dynamics of upwelling in the Alaskan Beaufort Sea and associated shelf-basin fluxes. Deep-Sea Res I 76:35-51

Pieńkowski AJ, England JH, Furze MF, MacLean B, Blasco S (2014) The late Quaternary environmental evolution of marine Arctic Canada: Barrow Strait to Lancaster Sound. Quat Sci Rev 91:184-203

Piepenburg D (2000) Arctic brittle stars (Echinodermata: Ophiuroidea). Oceanogr Mar Biol Annu Rev 38:189-256

Ping CL, Michaelson GJ, Guo L, Jorgenson MT, Kanevskiy M, Shur Y, Dou F, Liang J (2011) Soil carbon and material fluxes across the eroding Alaska Beaufort Sea coastline. J Geophys Res Biogeosci 116:G02004 
Post DM (2002a) The long and short of food-chain length. Trends Ecol Evol 17:269-277

Post DM (2002b) Using stable isotopes to estimate trophic position: models, methods and assumptions. Ecology 83: 703-718

R Development Core Team (2014) R: A language and environment for statistical computing. R Foundation for Statistical Computing, Vienna, Austria. www.r-project.org

Rachold V, Grigoriev MN, Are FE, Solomon S, Reimnitz E, Kassens H, Antonow M (2000) Coastal erosion vs riverine sediment discharge in the Arctic Shelf seas. Int J Earth Sci 89:450-460

Rachold V, Eicken H, Gordeev VV, Grigoriev MN and others (2004) Modern terrigenous organic carbon input to the Arctic Ocean. In: Stein R, Macdonald RW (eds) The organic carbon cycle in the Arctic Ocean. Springer, Heidelberg, p 33-55

Ravelo AM, Konar B, Bluhm BA (2015) Spatial variability of epibenthic communities on the Alaska Beaufort Shelf. Polar Biol 38:1783-1804

Raymond PA, McClelland JW, Holmes RM, Zhulidov AV and others (2007) Flux and age of dissolved organic carbon exported to the Arctic Ocean: a carbon isotopic study of the five largest arctic rivers. Global Biogeochem Cycles 21:GB4011

Reynolds PD (2006) Scaphopoda: the tusk shells. In: Sturm CF, Pearse TA, Valdes A (eds) The mollusks: a guide to their study, collection, and preservation. Universal Publishers, Boca Raton, FL, p 229-237

Robinson RS, Keinast M, Albuquerque AL, Altabet $\mathrm{M}$ and others (2012) A review of nitrogen isotopic alteration in marine sediments. Paleoceanography 27:PA4203

Rontani JF, Charrière B, Sempéré R, Doxaran D, Vaultier F, Vonk JE, Volkman JK (2014) Degradation of sterols and terrigenous organic matter in waters of the Mackenzie Shelf, Canadian Arctic. Org Geochem 75:61-73

Rosenzweig ML (1971) Paradox of enrichment: destabilization of exploitation ecosystems in ecological time. Science 171:385-387

Roy V, Iken KI, Gosselin M, Tremblay JÉ, Bélanger S, Archambault P (2015) Benthic faunal assimilation pathways and depth-related changes in food-web structure across the Canadian Arctic. Deep-Sea Res I 102:55-71

Sakshaug E (2004) Primary and secondary production in the Arctic seas. In: Stein R, Macdonald RW (eds) The organic carbon cycle in the Arctic Ocean. Springer, Heidelberg, p 57-81

Schell DM (1983) Carbon-13 and carbon-14 abundances in Alaskan aquatic organisms: delayed production from peat in Arctic food webs. Science 219:1068-1071

Schell DM, Ziemann PJ, Parrish DM, Dunton KH, Brown EJ (1982) Foodweb and nutrient dynamics in nearshore Alaska Beaufort Sea waters. OCSEAP Final Rep 25, p 327-499. US Department of Commerce, NOAA, Anchorage, AK

Schell DM, Barnett BA, Vinette KA (1998) Carbon and nitrogen isotope ratios in zooplankton of the Bering, Chukchi and Beaufort seas. Mar Ecol Prog Ser 162: 11-23

Schlacher TA, Connolly RM (2014) Effects of acid treatment on carbon and nitrogen stable isotope ratios in ecological samples: a review and synthesis. Methods Ecol Evol 5: 541-550

Editorial responsibility: Robert Condon, Wilmington, North Carolina, USA
Schlitzer R (2011) 'Ocean data view version 4.5.3'. Alfred Wegener Institute for Polar and Marine Research, Bremerhaven

Sipler RE, Bronk DA (2015) Dynamics of dissolved organic nitrogen. In: Carlson DAHA (ed) Biogeochemistry of marine dissolved organic matter, 2nd edn. Academic Press, Boston, MA, p 127-232

Søreide JE, Hop H, Carroll ML, Falk-Petersen S, Hegseth EN (2006) Seasonal food web structures and sympagicpelagic coupling in the European Arctic revealed by stable isotopes and a two-source food web model. Prog Oceanogr 71:59-87

Sun MY, Carroll ML, Ambrose WG Jr, Clough LM, Zou L, Lopez GR (2007) Rapid consumption of phytoplankton and ice algae by Arctic soft-sediment benthic communities: evidence using natural and ${ }^{13} \mathrm{C}$-labeled food materials. J Mar Res 65:561-588

Tank SE, Manizza M, Holmes RM, McClelland JW, Peterson BJ (2012) The processing and impact of dissolved riverine nitrogen in the Arctic Ocean. Estuaries Coasts 35: 401-415

- Tenore KR (1983) What controls the availability to animals of detritus derived from vascular plants: organic nitrogen enrichment or caloric availability? Mar Ecol Prog Ser 10: 307-309

Terazaki M (1998) Life history, distribution, seasonal variability and feeding of the pelagic chaetognath Sagitta elegans in the Subarctic Pacific: a review. Plankton Biol Ecol 45:1-17

Tremblay JÉ, Bélanger S, Barber DG, Asplin M and others (2011) Climate forcing multiplies biological productivity in the coastal Arctic Ocean. Geophys Res Lett 38:L18604, doi:10.1029/2011GL048825

> Vallières C, Retamal L, Ramlal P, Osburn CL, Vincent WF (2008) Bacterial production and microbial food web structure in a large Arctic river and the coastal Arctic Ocean. J Mar Syst 74:756-773

> Vander Zanden MJ, Rasmussen JB (1999) Primary consumer $\delta^{13} \mathrm{C}$ and $\delta^{15} \mathrm{~N}$ and the trophic position of aquatic consumers. Ecology 80:1395-1404

Vander Zanden MJ, Rasmussen JB (2001) Variation in $\delta^{15} \mathrm{~N}$ and $\delta^{13} \mathrm{C}$ trophic fractionation: implications for aquatic food web studies. Limnol Oceanogr 46:2061-2066

Wassmann P, Duarte CM, Agustí S, Sejr MK (2011) Footprints of climate change in the Arctic marine ecosystem. Glob Change Biol 17:1235-1249

> Weems J, Iken K, Gradinger R, Wooller MJ (2012) Carbon and nitrogen assimilation in the Bering Sea clams Nuculana radiata and Macoma moesta. J Exp Mar Biol Ecol 430-431:32-42

Williams WJ, Carmack EC, Shimada K, Melling H, Aagaard K, Macdonald RW, Ingram RG (2006) Joint effects of wind and ice motion in forcing upwelling in Mackenzie Trough, Beaufort Sea. Cont Shelf Res 26:2352-2366

Wooller MJ, Zazula GD, Edwards M, Froese DG, Boone RD, Parker C, Bennett B (2007) Stable carbon isotope compositions of Eastern Beringian grasses and sedges: investigating their potential as paleoenvironmental indicators. Arct Antarct Alp Res 39:318-331

Yokoyama H, Tamaki A, Harada K, Shimoda K, Koyama K, Ishihi Y (2005) Variability of diet-tissue isotopic fractionation in estuarine macrobenthos. Mar Ecol Prog Ser 296: $115-128$

Submitted: July 13, 2015; Accepted: April 6, 2016

Proofs received from author(s): May 12, 2016 